\title{
Impact of open crop residual burning on air quality over Central Eastern China during the Mount Tai Experiment 2006 (MTX2006)
}

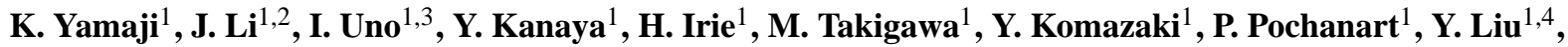 \\ H. Tanimoto ${ }^{5}$, T. Ohara ${ }^{5}$ X. Yan $^{6}$, Z. Wang ${ }^{2}$, and H. Akimoto ${ }^{1, *}$ \\ ${ }^{1}$ Japan Agency for Marine-Earth Science and Technology, 3173-25, Showa-machi, Kanazawa-ku, Yokohama, Kanagawa \\ 236-0001, Japan \\ ${ }^{2}$ LAPC and NZC, Institute of Atmospheric Physics, Chinese Academy of Sciences, Beijing 10029, China \\ ${ }^{3}$ Research Institute for Applied Mechanics, Kyushu University, Kasuga Park 6-1, Kasuga 816-8580, Fukuoka, Japan \\ ${ }^{4}$ Institute of Atmospheric Physics, Chinese Academy of Sciences, Beijing 10029, China \\ ${ }^{5}$ National Institute for Environmental Studies, 16-2, Onogawa, Tsukuba, Ibaraki 305-8506, Japan \\ ${ }^{6}$ Institute of Soil Science, Chinese Academy of Sciences, Nanjing 210008, China \\ *now at: Asia Center for Air Pollution Research, 1182 Sowa, Nishi-ku, Niigata, Japan
}

Received: 29 September 2009 - Published in Atmos. Chem. Phys. Discuss.: 21 October 2009

Revised: 12 July 2010 - Accepted: 12 July 2010 - Published: 9 August 2010

\begin{abstract}
The impact of open crop residual burning (OCRB) on $\mathrm{O}_{3}, \mathrm{CO}$, black carbon (BC) and organic carbon (OC) concentrations over Central Eastern China (CEC; $30-40^{\circ} \mathrm{N}$, $111-120^{\circ} \mathrm{E}$ ), during the Mount Tai Experiment in 2006 (MTX2006) was evaluated using a regional chemical transport model, the Models-3 Community Multiscale Air Quality Modeling System (CMAQ). To investigate these pollutants during MTX2006 in June 2006, daily gridded OCRB emissions were developed based on a bottom-up methodology using land cover and hotspot information from satellites. This model system involving daily emissions captured monthly-averages of observed concentrations and day-today variations in the patterns of $\mathrm{O}_{3}, \mathrm{CO}, \mathrm{BC}$ and $\mathrm{OC}$ at the summit of Mount Tai $\left(36^{\circ} \mathrm{N}, 117^{\circ} \mathrm{E}, 1534 \mathrm{~m}\right.$ a.s.l., Shandong Province of the People's Republic of China) with high correlation coefficients between the model and observations ranging from 0.55 to 0.69 . These results were significantly improved from those using annual biomass burning emissions. For monthly-averaged $\mathrm{O}_{3}$, the simulated concentration of $80.8 \mathrm{ppbv}$ was close to the observed concentration (81.3 ppbv). The MTX2006 period was roughly divided into two parts: 1) polluted days with heavy OCRB in the first half of June; and 2) cleaner days with negligible field burning in the latter half of June. Additionally, the first half of June was characterized by two high-pollution episodes during 5-7 and 12-13 June, separated by a relatively cleaner intermediate period during 8-10 June. In the first high-pollution episode,
\end{abstract}

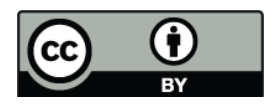

Correspondence to: K. Yamaji (kazuyo@jamstec.go.jp) the model captured the high $\mathrm{O}_{3}, \mathrm{CO}, \mathrm{BC}$ and $\mathrm{OC}$ concentrations at the summit of Mount Tai, which were associated with OCRB over southern CEC and subsequent northward transport. For this episode, the impacts of OCRB emissions on pollutant concentrations were $26 \%\left(\mathrm{O}_{3}\right), 62 \%(\mathrm{CO}), 79 \%$ (BC) and $80 \%$ (OC) at the summit of Mount Tai. The daily OCRB emissions were an essential factor in the evaluation of these pollutants during MTX2006. These emissions have a large impact not only on primary pollutants but also on secondary pollutants, such as $\mathrm{O}_{3}$, in the first half of June over northeastern Asia. The model reproduced reasonably well the variation of these pollutants in MTX2006, but underestimated daily averages of both $\mathrm{CO}$ and $\mathrm{BC}$ by a factor of 2 , when using emission data from almost solely anthropogenic fuel sources in the latter half of the observation period when field burning can be neglected.

\section{Introduction}

Central Eastern China (CEC), located at 30-40 N, 111$120^{\circ} \mathrm{E}$, (Fig. 1) has received considerable attention as a region containing trace gases and aerosol pollutants, which are causative agents of serious air pollution and important components contributing to global radiation budgets. Several studies of bottom-up emission inventory have shown that CEC is one of the largest emission source areas in the world for all anthropogenic sectors (Olivier et al., 1999; Streets et al., 2003; Ohara et al., 2007).

Recently, tropospheric satellite observations have demonstrated that emissions of the major $\mathrm{O}_{3}$ precursor, $\mathrm{NO}_{\mathrm{x}}$, in

Published by Copernicus Publications on behalf of the European Geosciences Union. 
CEC have accelerated since 2000 (Richter et al., 2005; Irie et al., 2005, 2009). Richter et al. (2005) found a highly significant increase over the industrial area of China which was higher than that demonstrated in a bottom-up inventory by Streets et al.(2000). Even during 1998-2000, Uno et al. (2007) found that $\mathrm{NO}_{2}$ levels observed by the Global Ozone Monitoring Experiment (GOME) satellite had increased more than those simulated using the Models-3 Community Multiscale Air Quality Modeling System (CMAQ) and a bottom-up emission inventory, Regional Emission Inventory in Asia (REAS) (Ohara et al., 2007). Many recent studies have indicated that significant uncertainties may exist in most emission inventories for pollutants from Asia in general and from East Asia in particular, especially for $\mathrm{CO}$ (e.g. Kasibhatla et al., 2002; Pétron et al., 2002; Kiley et al., 2003; Palmer et al., 2003; Carmichael et al., 2003; Arellano et al., 2004; Allen et al., 2004; Tan et al., 2004). A modeling study using the Regional Acid Deposition Model (RADM) with the ACE-Asia and TRACE-P Modeling and Emission Support System (ACESS) (Streets et al., 2003) for Lin'an $\left(30^{\circ} \mathrm{N}, 119^{\circ} \mathrm{E}, 132 \mathrm{~m}\right.$ a.s.l., Zhejiang Province, People's Republic of China) suggested that a $50 \%$ increase in emissions would bring the model-calculated concentrations into agreement with observations (Tan et al., 2004). Subsequently, Streets et al. (2006) showed that China's CO emission was $157 \mathrm{Tg} \mathrm{yr}^{-1}$ in 2001, which was $36 \%$ higher than the ACESS estimate $\left(116 \mathrm{Tg} \mathrm{yr}^{-1}\right)$ for the year 2000 (Streets et al., 2003).

Observational and modeling studies of air quality over CEC have been initiated at the summits of three mountains in CEC: Mount Tai $\left(36^{\circ} \mathrm{N}, 117^{\circ} \mathrm{E}, 1534 \mathrm{~m}\right.$ a.s.l., Shandong), Mount Hua $\left(34^{\circ} \mathrm{N}, 110^{\circ} \mathrm{E}, 2064 \mathrm{~m}\right.$ a.s.l., Shaanxi) and Mount Huang $\left(30^{\circ} \mathrm{N}, 118^{\circ} \mathrm{E}, 1836 \mathrm{~m}\right.$ a.s.l., Anhui) (cf. Fig. 1), which are remote rural sites representative of the regions within CEC. These studies have indicated that monthly-averaged $\mathrm{O}_{3}$ peaks usually appear in June, with more than $60 \mathrm{ppbv}$, and the maximum hourly $\mathrm{O}_{3}$ reached during 2004-2006 was 150 ppbv (Li et al., 2007; He et al., 2008). In particular, the monthly-averaged $\mathrm{O}_{3}$ at the summit of Mount Tai exceeded 80 ppbv in June (Li et al., 2007; He et al., 2008). Gao et al. (2005) indicated that monthly-averaged $\mathrm{O}_{3}$ (65 ppbv) and $\mathrm{CO}(439 \mathrm{ppbv})$ peaked in July during an observational period spanning July-November 2003. Several regional modeling studies ( $\mathrm{Li}$ et al., 2007; He et al., 2008; Yamaji et al., 2008) captured this seasonal cycle peaking in early summer (June-July), but systematically failed to simulate such high concentrations. In our previous modeling study using annual biomass burning emissions from ACESS (Streets et al., 2003), simulated $\mathrm{O}_{3}$ reproduced well the seasonal variations in observed values at remote Japanese sites, but the monthly-averaged $\mathrm{O}_{3}$ was underestimated by 5-15 ppbv at the summit of Mount Tai in June (Yamaji et al., 2008). From the viewpoint of emissions from CEC, these underestimates were likely caused by rapid increases in anthropogenic emissions after 2000, in addition to uncertainties

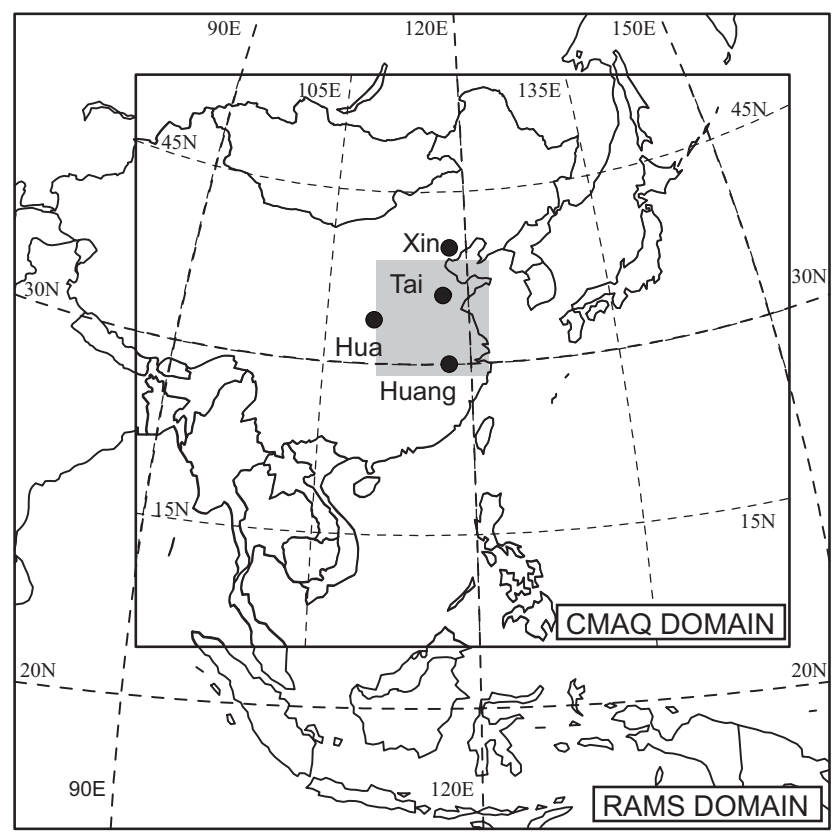

Fig. 1. Model domains for CMAQ (inside) and RAMS (outside) simulations. Tai (Mount Tai) $\left(36^{\circ} \mathrm{N}, 117^{\circ} \mathrm{E}, 1533 \mathrm{~m}\right.$ a.s.l.), Hua (Mount Hua) $\left(34^{\circ} \mathrm{N}, 110^{\circ} \mathrm{E}, 2064 \mathrm{~m}\right.$ a.s.1.), Huang (Mount Huang) $\left(30^{\circ} \mathrm{N}, 118^{\circ} \mathrm{E}, 1836 \mathrm{~m}\right.$ a.s.1.), and Xin (Xinglong) $\left(40^{\circ} \mathrm{N}, 118^{\circ} \mathrm{E}\right.$, $960 \mathrm{~m}$ a.s.1.) are shown. The domain with a dark gray shadow is defined as Central Eastern China (CEC).

in the temporal and spatial distributions of biomass burning (Yamaji et al., 2008).

As part of an intensive field observation campaign at the summit of Mount Tai, the Mount Tai Experiment 2006 (MTX2006) was carried out in June 2006 to evaluate the emission sources, tropospheric chemistry, transformation and transport of atmospheric pollutants, $\mathrm{O}_{3}$, aerosols, and their precursors over CEC. Mount Tai is free from local sources but is located at the center of a regionally polluted area of CEC. Considerably high-pollution episodes were observed in the first half of June, which were attributed to significant open crop residual burning (OCRB) (Kanaya et al., 2008; Li et al., 2008a). As discussed later, a large number of hotspots were detected by the Aqua/Terra Moderate resolution Imaging Spectroradiometer (MODIS) over the southern parts of Mount Tai. The State Environmental Protection Administration (SEPA) in China also reported that the fire events seemed to be strongly associated with agricultural waste burning in the field after the wheat harvest. Therefore, a cause for the underestimation in our previous model study (Yamaji et al., 2008) likely comes from the lack of temporal distribution data in the annual biomass burning emission inventory. In addition, we found that the spatial distributions of gridded emissions for biomass burning in ACESS (Streets et al., 2003) did not necessarily correspond to the hotspot positions for the year 2006. Even in the revised ACESS 
inventory, Streets et al. (2006) admitted to an uncertainty regarding the magnitude of $\mathrm{CO}$ emissions from OCRB.

In this study, the impact of OCRB on regional $\mathrm{O}_{3}, \mathrm{CO}$, black carbon (BC) (or elemental carbon (EC)) and organic carbon (OC) concentrations was examined using a regional chemical transport model (CTM) driven by daily biomass burning emissions during the MTX2006. Details of the regional CTM employed in this study are provided in Sect. 2. In Sect. 3, we describe the emission inventory used in this study, with a focus on daily gridded emissions from OCRB in China in particular. We report the results of day-to-day variations in pollutants at the summit of Mount Tai and their spatial distributions over northeast Asia based on the regional CTM results obtained using daily emissions from OCRB in Sect. 4.

\section{Regional chemical transport model system and sensitivity experiment design}

The modeling system employed in this study was CMAQ version 4.4 (Byun and Ching, 1999) driven by the meteorological fields calculated by the Regional Atmospheric Modeling System (RAMS) version 4.4 (Pielke et al., 1992; Cotton et al., 2003). The RAMS simulation used the National Centers for Environmental Prediction (NCEP) global tropospheric analyses with a 1.0 degree resolution at 6-hourly intervals for the year 2006 data set. The off-line processor for combining CMAQ with RAMS was developed by Uno et al. (2007). Subsequently, Yamaji et al. (2006, 2008) compared simulated $\mathrm{O}_{3}$ concentrations with observed $\mathrm{O}_{3}$ over the Sea of Japan region provided by the Acid Deposition East Asia Monitoring Network (EANET) and World Data Centre for Greenhouse Gases (WDCGG), and with observed $\mathrm{O}_{3}$ at the summit of Mount Tai.

Spatial domains for CMAQ and RAMS shown in Fig. 1 are $6240 \times 5440 \mathrm{~km}^{2}$ (the inner domain) and $8000 \times 5600 \mathrm{~km}^{2}$ (the outer domain) on rotated polar stereographic map projections centered at $25^{\circ} \mathrm{N}$ and $115^{\circ} \mathrm{E}$, respectively, with an $80 \times 80 \mathrm{~km}^{2}$ grid resolution. For the vertical resolution, both model systems have the same model height of $23 \mathrm{~km}$ and employ a hybrid sigma-pressure coordinate. CMAQ and RAMS has 14 and 23 vertical layers, respectively. Both have 7 layers below $2 \mathrm{~km}$.

The CMAQ chemical-transport model (CCTM) requires information for the initial and boundary chemical concentrations. We used an initial condition to reflect chemical concentrations in East Asia; these conditions were applied to the CMAQ simulations by Zhang et al. (2002) and Yamaji et al. $(2006,2008)$. The boundary conditions of $\mathrm{O}_{3}$ and its precursors, $\mathrm{NO}, \mathrm{NO}_{2}, \mathrm{CO}$, ethane and propane were obtained from daily averaged concentrations by the chemical AGCM for study of atmospheric environment and radiative forcing (CHASER) (Sudo et al., 2002a; Sudo and Akimoto, 2007). The CCTM simulates the relevant and major atmospheric
Table 1. Sensitivity model experiment designs.

\begin{tabular}{lll}
\hline \multicolumn{2}{c}{ Emissions } \\
\hline 06DS & $\begin{array}{l}\text { REAS }^{\mathrm{a}} \\
\text { Year 2006, estimated }\end{array}$ & $\begin{array}{l}\text { Open biomass burning } \\
\text { Daily, smoothed daily } \\
\text { hotspot data } \\
\text { Daily, observed daily } \\
\text { hotspot data } \\
\text { 06D }\end{array}$ Year 2006, estimated \\
00DS & Year 2006, estimated & $\begin{array}{l}\text { Ynual, annual hotspot } \\
\text { data 2000, bottom up } \\
\text { Daily, smoothed daily } \\
\text { hotspot data } \\
\text { NODRB }\end{array}$ Year 2006, estimated \\
\hline
\end{tabular}

a Regional emission inventory in Asia (Ohara et al., 2007), b Using a bottom-up methodology by Yan et al. (2006) for annual emissions estimation and the MODIS (MOerate resolution Imaging Spectroradiometer) fire database for the spatial and temporal allocations, Here, "yyTH" means that: (yy) base year of REAS, 2000 or $2006(00$ or 06$) ;(T)$ time resolution of emissions from open biomass burning, daily or annual (D or A); (H) hotspot data used to divide into each time resolution, smoothed daily, observed daily, or annual hotspot data (S, O, or A).

gas chemistry, transport, and deposition processes. For the gas-phase atmospheric chemical mechanisms, the Statewide Air Pollution Research Center (SAPRC)-99 (Carter, 2000), which has documented 72 chemical species and 214 chemical reactions (including 30 photochemical reactions), was employed with the mechanism-specific Euler Backward Iterative (EBI) solver. We also used the 3rd generation CMAQ aerosol module (AERO3), which includes SORGAM (Schell et al., 2001) as a secondary organic aerosol model, ISSOROPIA (Nenes et al., 1998) as an inorganic aerosol model, and RPM (Binkowski and Shankar, 1995) as a regional particulate model.

The model simulation for the present study started on 1 May 2006. The first month of simulation is regarded as the spin-up and the following month of simulation was used in the analysis. The chemical concentrations used in this study are the instantaneous CCTM outputs obtained every three hours starting at 00:00 UTC each day. In following sections, the model output in a layer at $1300-1600 \mathrm{~m}$ altitude assumed as the simulated results at the summit of Mount Tai.

For sensitivity model experiments on emissions, we employed five model designs listed in Table 1: 06DS using REAS for the year 2006 and daily open biomass burning emissions for the year 2006 based on smoothed hotspot data; 06DO using REAS for the year 2006 and daily open biomass burning emissions for the year 2006 based on observed hotspot data; 06AA using REAS for the year 2006 and annual biomass burning emissions for the year 2006; 00DS using REAS for the year 2000 and daily biomass burning emissions for the year 2006 based on smoothed hotspot data: and NOCRB using REAS for the year 2006 without OCRB emissions. 
Table 2. Emissions from open biomass burning in China $\left(\mathrm{Gg}\right.$ species $\left.\mathrm{yr}^{-1}\right)$.

\begin{tabular}{|c|c|c|c|c|c|c|c|c|}
\hline & Year & $\mathrm{NO}_{\mathrm{x}}\left(\right.$ as $\left.\mathrm{NO}_{2}\right)$ & $\mathrm{SO}_{2}$ & $\mathrm{CO}$ & $\mathrm{NH}_{3}$ & $\mathrm{EC}$ & $\mathrm{OC}$ & NMVOC \\
\hline \multicolumn{9}{|c|}{ Field burning of crop residue } \\
\hline This study & 2006 & 528 & 55 & 12673 & 179 & 95 & 455 & 2163 \\
\hline Yan et al. (2006) & 2000 & 468 & 49 & 11231 & 159 & 84 & 403 & 1917 \\
\hline $\operatorname{ACESS}^{\mathrm{a}}$ & 2001 & 403 & 42 & 9691 & 137 & 73 & 348 & 1654 \\
\hline \multicolumn{9}{|c|}{ Forest and grassland fires } \\
\hline Yan et al. $(2006)^{b}$ & 2000 & 266 & 53 & 5791 & 77 & 31 & 486 & 1160 \\
\hline $\operatorname{ACESS}^{\mathrm{a}}$ & 2001 & 413 & 40 & 6051 & 89 & 40 & 380 & 1037 \\
\hline
\end{tabular}

${ }^{a}$ Streets et al. (2003) (available at http://www.cgrer.uiowa.edu/ACESS/acess_index.htm), ${ }^{\mathrm{b}}$ These emissions from forest and grassland fires were used in this study. Chinese provinces level emissions are shown in a supplementary table.

\section{Emissions}

\subsection{Annual and monthly emissions estimation}

\subsubsection{Emissions from OCRB in China}

After harvest, crop residue is either directly returned to agriculture fields as fertilizer, burned in the field, or used as biofuel. However, it is difficult to obtain accurate estimates of the management of these crop residues because of the lack of relevant statistical data. Gao et al. (2002) prepared a crop residue balance sheet for 21 provinces in China based on extensive survey data, in which only $6.6 \%$ of the crop residue was burned in the field, and on average $36.6 \%$ of the crop residue was directly returned to the soil. However, most other experts estimated around 15-20\% of crop residues were directly returned to the soil (Yang, 1994; Song, 1995; MOA/DOE Project Expert Team, 1998; Li, 2003). The percentages calculated by Gao et al. (2002) for crop residue returned to the soil were overestimated by $16.6-21.6 \%$. Therefore, Yan et al. (2006) recommended adding $16.6 \%$ to the percentage for each province. However, this adjustment was not applied to provinces where more than $30 \%$ of the crop residue was burned in the field (Gao et al., 2002). For the other provinces not listed in the study by Gao et al. (2002), either the percentages in a neighboring province with the most similar conditions or the national average $(19.4 \%)$ were used. We used the adjustment percentages recommended by Yan et al. (2006) in this study. In particular, for several provinces surrounding Mount Tai, we employed the following percentages: $19.6 \%$ (Shandong), 17.5\% (Anhui), 22.4\% (Henan), $11.3 \%$ (Hebei), and 33.9\% (Jiangsu). Fig. 2 shows the locations of these provinces together with fire counts in June which will be discussed later. The residue quantities for major crops were obtained from the grain yield (Editorial Board of China Agricultural Statistical Yearbook, 2007) and the residue/grain ratio (Yan et al., 2006). The emission factors from Andreae and Merlet (2001) were used here, and have also been cited by the other inventories (Streets et al., 2003; Yan et al., 2006).
To estimate annual emissions from OCRB in each province, we employed a bottom-up methodology by Yan et al. (2006), in which the emissions for the year 2000 were estimated from biomass consumption and emission factors. Annual emissions $\left(\mathrm{NO}_{\mathrm{x}}, \mathrm{SO}_{2}, \mathrm{CO}, \mathrm{NH}_{3}\right.$, primary elemental carbon (PEC), primary organic carbon (POC), and NMVOC) from OCRB in China for the year 2006 were updated from Yan et al. (2006). All species increased by roughly $13 \%$ in the period 2000-2006, due to an increase in agricultural production (Table 2). In some provinces (Helongjian, Jinlin, Liaoning, Inner Mongolia, Ningxia, and Shanxi) and a city (Tianjing) (cf. Fig. 2), the emissions increased by more than $30 \%$ during this period. Shandong province (where Mount Tai is located) and its nearby provinces (Hebei, Henan, and Anhui provinces) with the exception of Jiangsu province showed emissions increases of 8-28\% during 2000-2006. In the other cities (Beijing, Shanghai, and Chongqing) and provinces (Guangdong, Guizhou, Hainan, Hunan, Jiangsu, Sichuan, and Zhejiang) (cf. Fig. 2), the emissions decreased by a few percent up to $50 \%$. The annual emissions from OCRB were $66 \%\left(\mathrm{NO}_{\mathrm{x}}\right), 51 \%\left(\mathrm{SO}_{2}\right), 69 \%(\mathrm{CO}), 70 \%$ $\left(\mathrm{NH}_{3}\right), 75 \%$ (PEC), $48 \%$ (POC) and 65\% (NMVOC) of annual emissions from open biomass burning in China. In the OCRB in China used in these model experiments, the annual emissions accounted for $66 \%\left(\mathrm{NO}_{\mathrm{x}}\right), 51 \%\left(\mathrm{SO}_{2}\right), 69 \%(\mathrm{CO})$, $70 \%\left(\mathrm{NH}_{3}\right), 75 \%$ (PEC), $48 \%$ (POC) and 65\% (NMVOC) of Chinese emissions from total open biomass burning.

As shown in Table 2, estimated emissions from Chinese OCRB by Yan et al. (2006) were larger than those of ACESS (Streets et al., 2003) by approximately $16 \%$, which was mainly caused by a difference in the estimated amounts of burned dry matter in the fields. The differences between Yan et al. (2006) and ACESS (Streets et al., 2003) for forest and grassland fires were also caused by differing estimates of the amounts of burned biomass.

\subsubsection{Emissions from forest and grassland burning}

Yan et al. (2006) estimated pollutant emissions from forest and grassland fires in China based on both satellite data and 


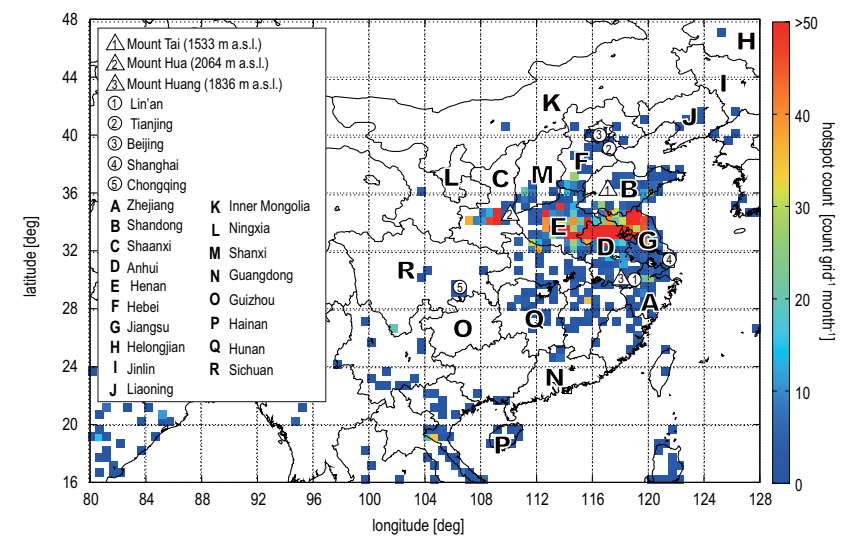

Fig. 2. Map of China with fire counts in June 2006.

statistics. They showed large discrepancies between satellite data and statistics; estimated amounts of burned biomass were 50.8 (satellite) and 2.1 (statistics) $\mathrm{Tg}$ dry matter $\mathrm{yr}^{-1}$ for forest fires or 5.5 (satellite) and 0.2 (statistics) Tg dry matter $\mathrm{yr}^{-1}$ for grassland fires (Yan et al., 2006). On the other hand, Streets et al. (2003) found $25 \mathrm{Tg}$ dry matter $\mathrm{yr}^{-1}$ for forest fires and $52 \mathrm{Tg}$ dry matter $\mathrm{yr}^{-1}$ for grassland fires in China, which was obtained by using fire statistical data for 1950 1992. It was shown that there are still large discrepancies between the amounts of burned biomass obtained using the different methodologies (Yan et al., 2006). For this simulation, the estimated emissions from forest and grassland fires are based on satellite data presented by Yan et al. (2006). Annual emissions from biomass burning in Asia, with the exception of China, were obtained from the ACESS final version (Streets et al., 2003).

\subsubsection{Anthropogenic emissions}

Annual atmospheric pollutant emissions $\left(\mathrm{NO}_{\mathrm{x}}, \mathrm{SO}_{2}, \mathrm{CO}\right.$, $\mathrm{NH}_{3}$, PEC, POC, and NMVOC) from anthropogenic sources (fossil fuel combustion, non-combustion industry, agriculture, and domestic activities) excluding biomass combustion in fields were based on REAS (Yan et al., 2003; Yamaji et al., 2003; Yamaji et al., 2004; Ohara et al., 2007). REAS, a bottom-up regional emission inventory for Asia with a 0.5 degree spatial resolution, provides a sequence of gridded emission data from the past (from 1980 to 2003) to the future (2010 and 2020) based on three emission scenarios, the reference (REF), the policy succeed case (PSC), and the policy failure case (PFC) scenarios. The future emissions predictions are based on the emissions in 2000 (Ohara et al., 2007). The PFC scenario may be more plausible when judged according to the recent trend in anthropogenic $\mathrm{NO}_{x}$ emissions in China after the year 2000, which increased from 11.2 in 2000 to $14.5 \mathrm{Tg} \mathrm{yr}^{-1}$ in 2003 , as reported by Akimoto et al. (2006) and Ohara et al. (2007). For this model study, therefore, the emissions data in the year 2006 were ob-
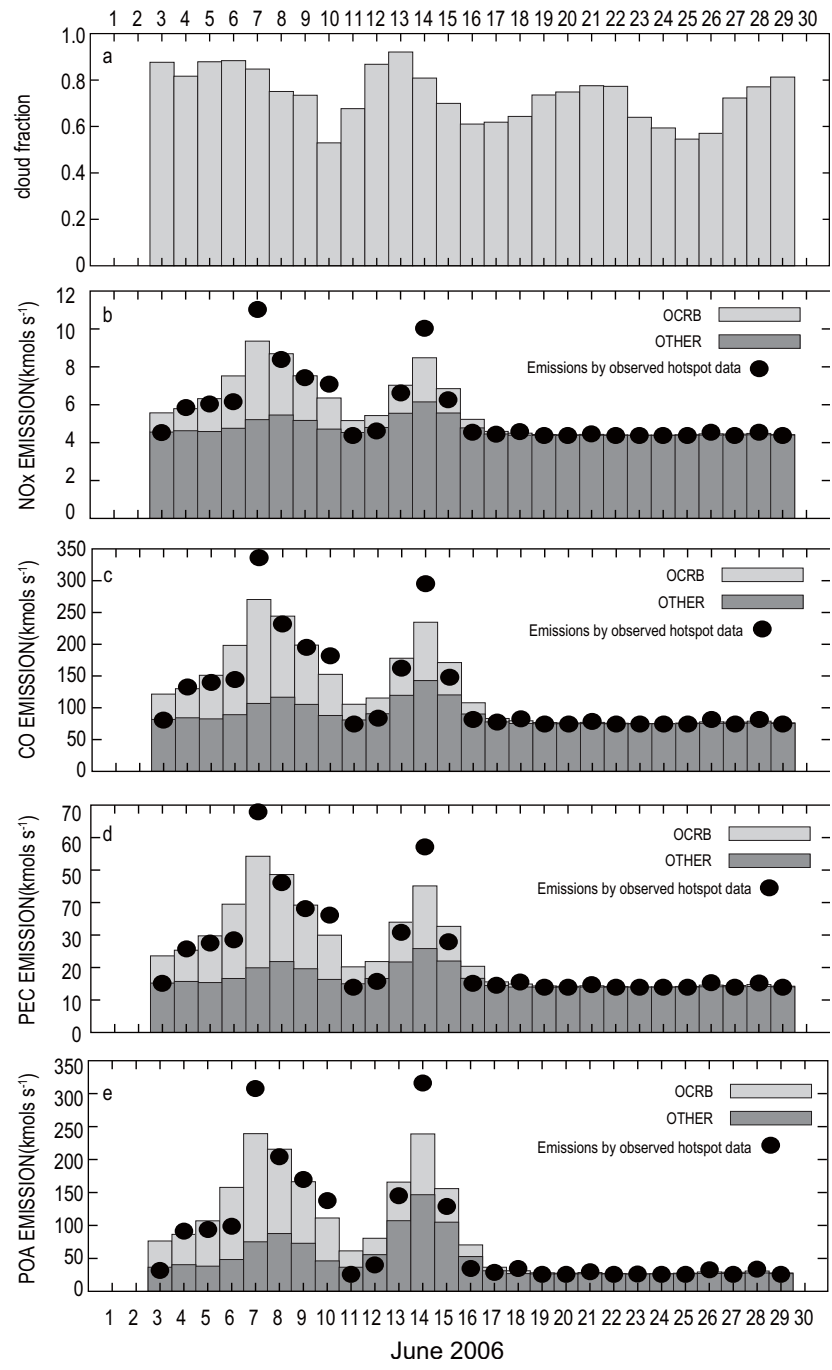

Fig. 3. Daily cloud fractions over East China $\left(20-40^{\circ} \mathrm{N}, 100-\right.$ $125^{\circ} \mathrm{E}$,) and emissions over $\mathrm{CEC}\left(30-40^{\circ} \mathrm{N}, 111-120^{\circ} \mathrm{E}\right)$. (a) Cloud fractions. The analyses used in this figure were produced with the Giovanni online data system, developed and maintained by the NASA GES DISC (Acker and Leptoukh, 2007). The daily (b) $\mathrm{NO}_{\mathrm{x}}$, (c) CO, (d) PEC and (e) POC emissions were divided using the smoothed (bars) and observed hotspot data (dots). OCRB is emissions from open crop residual burning. OTHER is emission from sources other than OCRB.

tained by simple interpolation using the values in 2003 and 2010 (PFC). For the major anthropogenic pollutants, $\mathrm{NO}_{\mathrm{x}}$ and $\mathrm{CO}$ in China, this model employed annual emissions of $15.5 \mathrm{Tg} \mathrm{yr}^{-1}$ for $\mathrm{NO}_{\mathrm{x}}$ and $165.1 \mathrm{Tg} \mathrm{yr}^{-1}$ for $\mathrm{CO}$. The $\mathrm{CO}$ emissions are close to estimated emissions (166.9 $\mathrm{Tg} \mathrm{yr}^{-1}$ ) by Zhang et al. (2009), but the $\mathrm{NO}_{\mathrm{x}}$ emissions are approximately $25 \%$ lower than their estimation. 

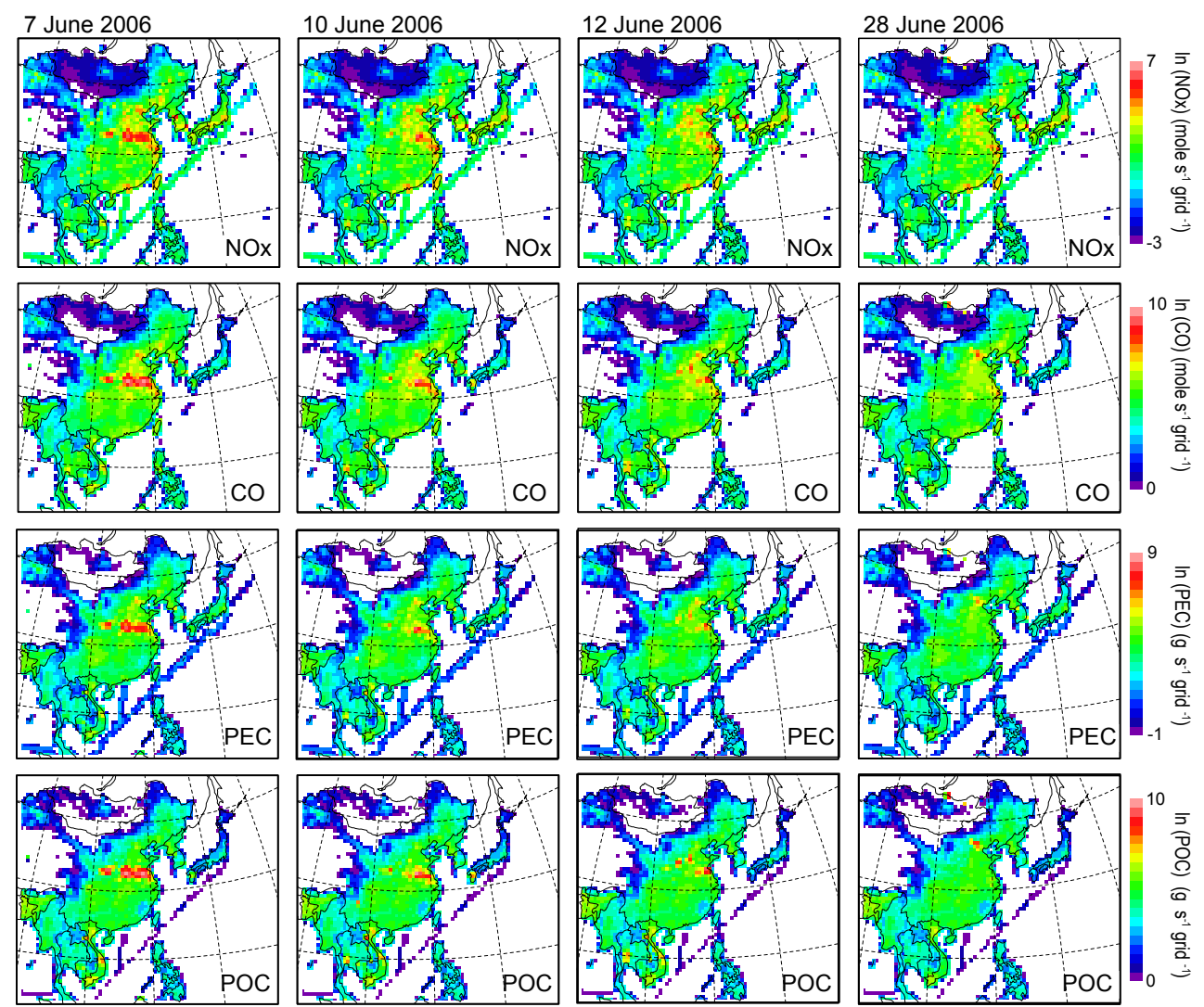

Fig. 4. Spatial distributions of daily $\mathrm{NO}_{\mathrm{x}}, \mathrm{CO}, \mathrm{PEC}$ and POC emissions from all sources on 7, 10, 12 and 28 June 2006.
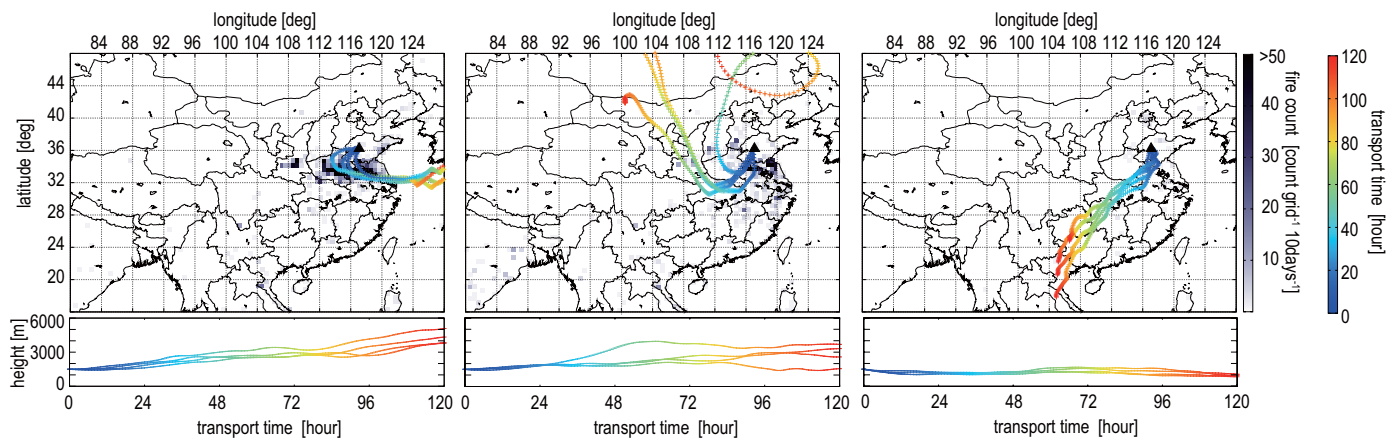

Fig. 5. Hotspot counts (count 10 days $^{-1}$ grid $^{-1}$ ) observed by Aqua/Terra MODIS for (a) 1-10 June, (b) 11-20 June, and (c) 21-30 June and backward trajectories calculated by the meteorological data explorer (CGER-METEX) on (a) 7 June, (b) 12 June, (c) 28 June.

\subsubsection{Natural emissions}

Biogenic NMVOC emissions, including isoprene and terpene, were obtained a $1^{\circ} \times 1^{\circ}$ monthly global inventory by Guenther et al. (1995). This global inventory overestimated the monthly mean $\mathrm{HCHO}$ columns over the northern and southern China in the growing season by $20-40 \%$ (Stavrakou et al., 2009). However, over Northern China in June for some years, the HCHO columns modeled by this inventory showed good agreement with observed columns. In this study, we employed the temporal and spatial distributions for these emissions by Guenther et al. (1995). Emissions from natural sources, e.g. soil and lightning $\mathrm{NO}_{\mathrm{x}}$, were not considered in our model simulations. In particular, REAS soil $\mathrm{NO}_{\mathrm{x}}$ emission from China in 2001 was estimated to be $400-500 \mathrm{Gg} \mathrm{N}$ $\mathrm{yr}^{-1}$, which is approximately $12-15 \%$ of combustion based $\mathrm{NO}_{\mathrm{x}}$. The reason for excluding soil and lightning $\mathrm{NO}_{\mathrm{x}}$ from the present simulation is that both sources are highly uncertain. 


\subsection{Daily gridded emissions}

The locations and timing of open biomass burning (OCRB and forest and grassland fires) are different from those of the other anthropogenic sources (e.g. fossil fuel combustion and non-combustion industry), and thus annual pollutant emissions from open biomass burning cannot be allocated over time and space in the same way as the other anthropogenic sources. OCRB is strongly correlated with agricultural practices, and forest and grassland fires are caused by both natural and human accidents (Streets et al., 2003). As shown in Fig 2, CEC was covered with a large number of hotspots in June, and that were strongly associated with OCRB after harvest. As mentioned in the previous section, additionally, an emission inventory for open biomass burning with the correct spatial and temporal distributions is needed to simulate the behavior of atmospheric pollutants in CEC in June. Therefore, for this simulation we tried to divide the annual emissions from open biomass burning in each of the Chinese provinces into daily gridded data at a 0.5 degree resolution based on satellite hotspots, the geographical information of the province and gridded land cover data. Since the Aqua/Terra MODIS provided more complete data for June 2006 than the NOAA AVHRR and ESA ATSR, Asian daily hotspot maps with a $1 \mathrm{~km}$ resolution, which are based on the MODIS fire database and available at http://webmodis.iis.u-tokyo.ac.jp, were employed in this study. However, the MODIS fire database could not capture all fire events occurring during this study period, because fires hidden under clouds could not be easily detected. In fact, the MODIS fire data included irregular no-fire days between large fire events. Figure 3 a shows the daily cloud fractions over East China $\left(20-40^{\circ} \mathrm{N}, 100-125^{\circ} \mathrm{E}\right)$ in June 2006. The daily cloud fractions exhibit the possibility that quite a lot of hotspots exist under the cloud. Additionally, satellite overpass also brings about the missed detection of hotspots. It is difficult to completely remove this uncertainty, therefore we employed the hotspot data that were smoothed with a 5-day weighted average for determining the emitting timings. The estimated annual emissions were divided into daily emissions using the smoothing-treated hotspot data. Simultaneously, the geographical information for each country or province based on the Gridded Population of the World version dataset (available at http://sedac.ciesin.org) and a gridded land cover database in the AARS Asia 30-s Land Cover Data Set with Ground Truth Information (available at http://www.cr.chiba-u.jp), were used to allocate the emissions inventory of country and province levels into each 0.5 degree grids. In this way, the diagnostication of the emitting timings relied on only the hotspots information from satellites for lack of a better way, therefore it should be noted that the satellites possibly could not capture small fire spots caused by a small-scale OCRB.

The selected emission maps of $\mathrm{NO}_{\mathrm{x}}, \mathrm{CO}, \mathrm{PEC}$ and POC from all emission sources on 7, 10, 12, and 28 June 2006 are shown in Fig. 4. Figures 5a-c depict corresponding hotspot counts observed by MODIS for 1-10, 11-20, 21-30 June overlapped with backward trajectories from Mount Tai on 7, 12 and 28 June, respectively. During the first half of June 2006, large numbers of hotspots were detected over the southern part of CEC and were found to be located to the south of Mount Tai (Fig. 5a and b). For the period on 7, 10, and 12 June 2006, high $\mathrm{NO}_{\mathrm{x}}, \mathrm{CO}, \mathrm{PEC}$ and POC emissions were detected over southern CEC (Fig. 4). On 7 June 2006, significantly high $\mathrm{NO}_{\mathrm{x}}, \mathrm{CO}, \mathrm{PEC}$ and POC emissions were found in southern $\mathrm{CEC}$, with fluxes per grid square reaching 450 moles s$^{-1}$ grid $^{-1}, \quad 17600$ moles s$^{-1}$ grid $^{-1}$, $3720 \mathrm{~g} \mathrm{~s}^{-1}$ grid $^{-1}$ and $16500 \mathrm{~g} \mathrm{~s}^{-1}$ grid $^{-1}$, respectively. Meanwhile, only a few hotspots were detected over China during the last 10 days in June (Fig. 5c), when the emissions were lower than those in the early June (Fig. 4). Approximately $40 \%$ of annual OCRB emissions in CEC were detected in June in 2006. About $14 \%$ of the monthly total (about $6 \%$ of the annual total) of the OCRB emissions were concentrated on 7 June. The daily total emissions and relative contribution from OCRB of $\mathrm{NO}_{\mathrm{x}}, \mathrm{CO}, \mathrm{PEC}$, and POA as shown in Figs. 3b-e, were $9 \mathrm{kmols} \mathrm{s}^{-1}$ and $44 \%\left(4 \mathrm{kmols} \mathrm{s}^{-1}\right), 270 \mathrm{kmols} \mathrm{s}^{-1}$ and $60 \%(163 \mathrm{kmols}$ $\left.\mathrm{s}^{-1}\right), 54 \mathrm{kmols} \mathrm{s}^{-1}$ and $63 \%\left(34 \mathrm{kmols} \mathrm{s}^{-1}\right)$, and $239 \mathrm{kmols}$ $\mathrm{s}^{-1}$ and $69 \%\left(164 \mathrm{kmols} \mathrm{s}^{-1}\right)$, respectively on 7 June. The impact of OCRB was particularly marked during 6-9 June, contributing 31-44\% $\left(\mathrm{NO}_{\mathrm{x}}\right.$ ), 47-61\% (CO), 50-63\% (PEC) and $56-69 \%$ (POA) of the total sources, respectively. The second largest peak appeared on 14 June with emissions (total and OCRB) of 8 and $2 \mathrm{kmols} \mathrm{s}^{-1}\left(\mathrm{NO}_{\mathrm{x}}\right), 234$ and $92 \mathrm{kmols} \mathrm{s}^{-1}$ (CO), 45 and $19 \mathrm{kmols} \mathrm{s}^{-1}$ (PEC), 238 and $92 \mathrm{kmols} \mathrm{s}^{-1}$ (POA). After 17 June, the impact of OCRB was almost zero, and the emission flux showed no day-today variation. By comparison with daily emissions based on the observed hotspot data, smoothing the hotspot data reduced daily emissions on 7, 10 and 14 June by $10-25 \%$ but increased emissions on other days.

\section{Results and discussion}

\subsection{General characteristics of observed pollutants}

As mentioned in Li et al. (2008a), the observation campaign period was roughly divided into two parts: 1) high-pollution days associated with heavy field burning of crop residue in the first half of June; and 2) cleaner days associated with negligible field burning in the latter half of June. Additionally, the first half of June was characterized by two high-pollution episodes during 5-7 and 12-13 June, and a relatively cleaner intermediate period during 8-10 June. Figure 6 shows the temporal variations of daily meteorological fields (wind and temperature) and daily $\mathrm{O}_{3}, \mathrm{CO}, \mathrm{BC}$ or $\mathrm{EC}$, and $\mathrm{OC}$ concentrations at the summit of Mount Tai. Mass concentrations of BC (or EC) were determined using four instruments, 

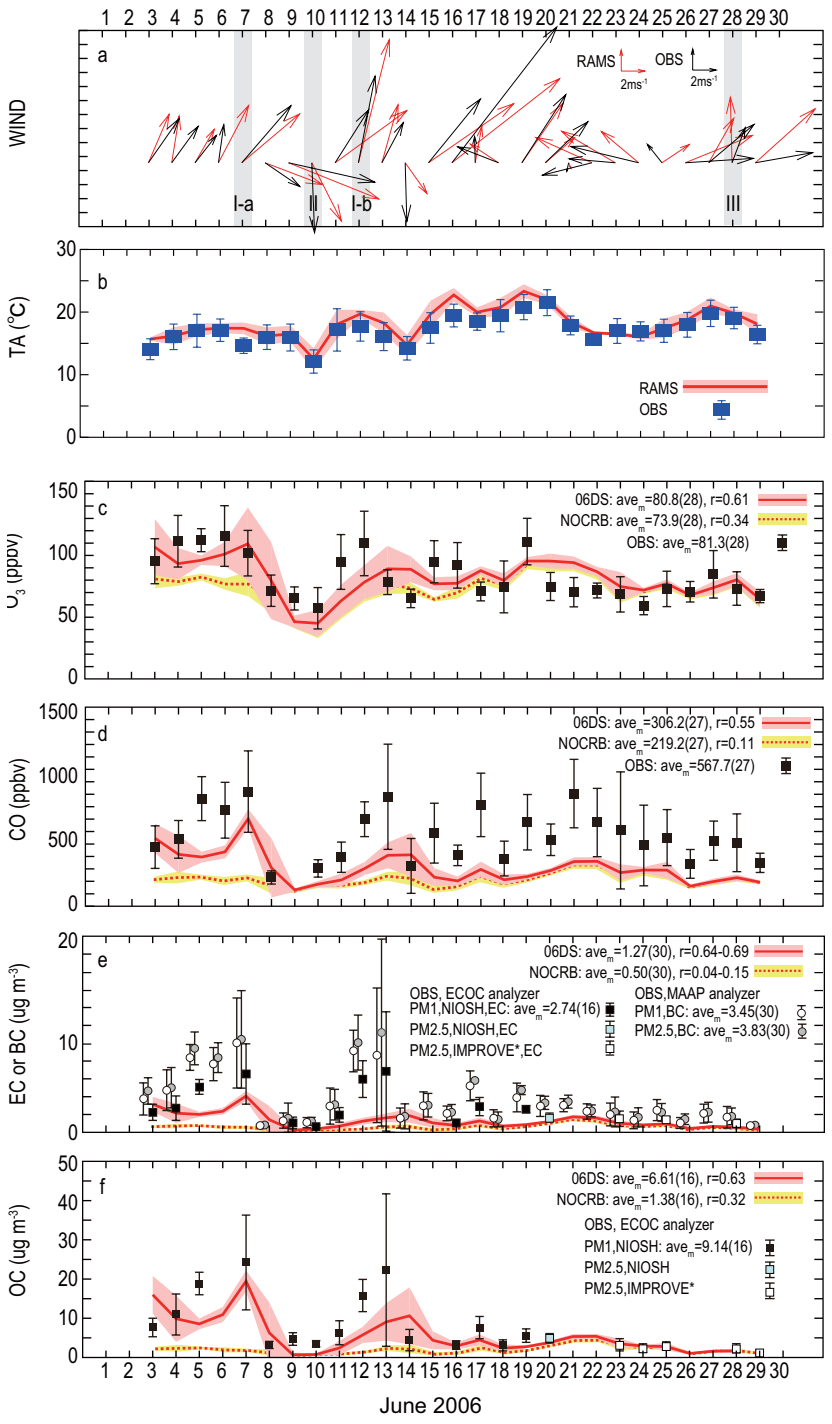

Fig. 6. Daily simulated and observed meteorological conditions and chemical concentrations at the summit of Mount Tai $\left(36^{\circ} \mathrm{N}\right.$, $117^{\circ} \mathrm{E}, 1533 \mathrm{~m}$ a.s.1.) in June 2006. (a) Simulated (RAMS) and observed (OBS) wind fields. (b) Simulated (RAMS, lines) and observed (OBS, squares) TA with SD $( \pm 1 \sigma)$ (simulated: shadow, observed: bars). Simulated (lines) and observed (squares) (c) $\mathrm{O}_{3}$, (d) $\mathrm{CO},(\mathbf{e}) \mathrm{EC}$ or BC, and (f) OC with $\mathrm{SD}( \pm 1 \sigma)$ (simulated: shadow, observed: bars). 06DS and NOCRB are simulated concentrations with and without daily emissions from open crop residual burning, respectively. ave $_{m}$ is monthly average with sample numbers in brackets. $\mathrm{r}$ is correlation coefficient. EC or BC was observed by ECOC analyzer (Sunset Laboratory) and MAAP analyzer (5012 MAAP, Thermo). OC was observed by ECOC analyzer (Sunset Laboratory) (Kanaya et al., 2008).

an ECOC semi-continuous analyzer (Sunset Laboratory), a multi-angle absorption photometer (5012 MAAP, Thermo), a particle soot absorption photometer (PSAP, Radiance Research), and an Aethalometer (AE-21, Magge Scientific) in the MTX2006 (Kanaya et al., 2009). At the same time, mass concentrations of OC were determined by the ECOC analyzer. The differences between these instruments were discussed in detail in Kanaya et al. (2009). The general magnitude relationship was shown to be $\mathrm{EC}\left(\mathrm{PM}_{1}, \mathrm{NIOSH}\right) \sim$ optEC $\left(\mathrm{PM}_{1}\right)<$ heated PSAP_BC $\left(\mathrm{PM}_{1}\right) \sim$ MAAP_BC $\left(\mathrm{PM}_{1}\right)$, and the largest discrepancy was found between $\mathrm{EC}\left(\mathrm{PM}_{1}\right.$, NIOSH) and MAAP_BC ( $\left.\mathrm{PM}_{1}\right)$, with a slope of 1.41.

The observed $\mathrm{O}_{3}$ and $\mathrm{CO}$ was considerably high, $81.3 \mathrm{ppbv}$ and $567.7 \mathrm{ppbv}$ for monthly average in June, respectively. Daily concentrations of $\mathrm{O}_{3}$ and $\mathrm{CO}$ within the two high-pollution episodes were relatively high (100-110 ppbv of $\mathrm{O}_{3}$ and 700-900 ppbv of $\mathrm{CO}$ ). $\mathrm{O}_{3}$ and $\mathrm{CO}$ kept high concentration levels (70-110 ppbv of $\mathrm{O}_{3}$ and $300-900 \mathrm{ppbv}$ of $\mathrm{CO})$ during June excepting the cleaner period, 8-10 June (Figs. 6c-d). The high-pollution episodes, especially for $\mathrm{BC}$ or EC, and $\mathrm{OC}$, are clearly evident on 5-7 June and 1213 June. The highest concentrations of BC $\left(10 \mu \mathrm{g} \mathrm{m}^{-3}\right)$ or EC $\left(7 \mu \mathrm{g} \mathrm{m}^{-3}\right)$, and OC $\left(24 \mu \mathrm{g} \mathrm{m}^{-3}\right)$ appeared on 7 June. In the other period, the both concentration levels were relatively low (Fig. 6e-f).

Trajectories shown in Figs. 5a and b suggest that on 7 and 12 June, the air masses passed through high-hotspot areas largely associated with OCRB and arrived at the summit of Mount Tai within almost 1 day. Suthawaree et al. (2010) found the same results in a study of a pollution episode on 7 June, obtained using alternative trajectory model (HYSPLIT4) and hotspot data (AVHRR). The southwesterly wind was observed at the summit of Mount Tai on 7 and 12 June (Fig. 6a). In the cleaner period, 8-10 June, on the other hand, the wind direction changed from the southwesterly wind to the northwesterly wind. The day-to-day variations of pollutants in the early half of June were clearly related to the air-mass paths and OCRB events. Figure $5 \mathrm{c}$ shows that air masses at the site are very weakly influenced by hotspots in the last 10 days of June. This typical pollution pattern in June was largely affected by a function of changing wind directions over CEC and the emissions associated with OCRB to the south of Mount Tai.

\subsection{Wind and temperatures by RAMS}

Figure 6a illustrates simulated and observed daily wind patterns at the summit of Mount Tai in June 2006. The simulated daily wind direction and speed agree reasonably well with the meteorological observations, although the simulated wind directions were occasionally 40-90 degrees different from observations. Consequently, differences could cause discrepancies between the simulated and observed pollutant concentrations. The daily-simulated ambient temperatures (TA) agreed reasonably well with observations (Fig. 6b). 


\subsection{Pollutants concentrations by CMAQ}

\subsection{1 $\mathrm{O}_{3}$ at the summit of Mount Tai}

Simulated daily $\mathrm{O}_{3}$ concentrations with (06DS, cf. Table 1) and without (NOCRB cf. Table 1) daily OCRB emissions are compared with daily $\mathrm{O}_{3}$ observations in Fig. 6c. Both sets of simulated $\mathrm{O}_{3}$ roughly captured the day-to-day variations of $\mathrm{O}_{3}$. A relatively low $\mathrm{O}_{3}$ period during 810 June was successfully reproduced by both models, because the meteorological model could reproduce well the change in wind direction from southwesterly to northwesterly (Fig. 6a). The run 06DS clearly captured the observed variations in daily-averaged $\mathrm{O}_{3}$ concentrations, with a correlation coefficient $(\mathrm{R})$ of 0.61 between the model and the observations. This value is much better than that obtained by NOCRB $(R=0.34)$. The simulated-monthly $\mathrm{O}_{3}$ concentration by $06 \mathrm{DS}(80.8 \mathrm{ppbv})$ was much closer than that by NOCRB (73.9 ppbv) comparing with observed monthly $\mathrm{O}_{3}$ concentration (81.3 ppbv). These results by 06DS are much better than that in our previous study (Yamaji et al., 2008) which underestimated by around 5-15 ppbv in June, because this model experiment (06DS) employed both updated anthropogenic emissions (energy and OCRB in China) considering recent economic growth during 2000-2006 in China and in detail spatial and daily OCRB emissions.

Observed high $\mathrm{O}_{3}$ of more than $100 \mathrm{ppbv}$ on 3-13 June was successfully captured by 06DS. On the other hand, this model tended to underestimate observed $\mathrm{O}_{3}$ of the second high-pollution episode (12-13 June) which was the same level as that of the first high-pollution episode. The simulated $\mathrm{O}_{3}$ peak seemed to be one day behind that of the observed peak on 12 June. This one-day delay was also shown by $\mathrm{Li}$ et al. (2008a), and that was related to the temporal distribution of emissions. As shown in Fig. $3 b-c$, the $\mathrm{O}_{3}$ precursors, e.g. $\mathrm{NO}_{\mathrm{x}}$ and $\mathrm{CO}$, emissions were estimated in 1112 June as the lowest of the early half of June. As for the observed $\mathrm{O}_{3}$ peak of 12 June, even if the strong south window pattern was simulated well, this peak could not be captured by this model affected by considerably low precursors' emissions. The simulated $\mathrm{O}_{3}$ peak appeared on 13 June, one day before of the emission peak (cf. Fig. 3b-c). Although this reason has been unclear yet, $\mathrm{O}_{3}$ that is a secondary pollutant might be affected according to not only its precursors' emissions nearby but also emissions and meteorological condition in the surrounding area. Meanwhile, the observed $\mathrm{O}_{3}$ concentration had a large diurnal variation because the wind shifted drastically from northeastward to southeastward on 13-14 June. As a result, the observed daily $\mathrm{O}_{3}$ concentration showed the relative lower peak on 14 June associated with the strong north wind. In the same time, this model sometime could not capture the large diurnal variation of wind direction and made the difference of approximately 40 degrees between the observed and the simulated daily wind directions (cf. Fig. 6a), and that seemed to make a little gap of the

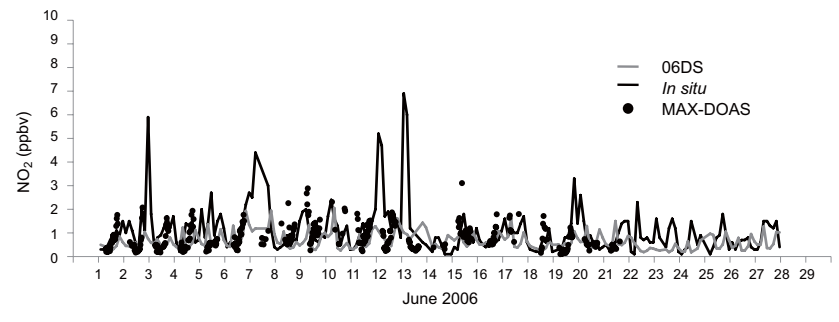

Fig. 7. Hourly $\mathrm{NO}_{2}$ concentrations at the summit of Mount Tai $\left(36^{\circ} \mathrm{N}, 117^{\circ} \mathrm{E}, 1533 \mathrm{~m}\right.$ a.s.1.). MAX-DOAS $\mathrm{NO}_{2}$ is the mean $\mathrm{NO}_{2}$ concentrations for the $1-2 \mathrm{~km}$ layer above surface at daytime.

lower $\mathrm{O}_{3}$ peak. The same problems were found in the second high-pollution episodes of $\mathrm{CO}, \mathrm{BC}$ and $\mathrm{OC}$. The difference between 06DS and NOCRB was negligibly small for 20-25 June, due to the reduced impact from OCRB. During 2025 June, daily-averaged $\mathrm{O}_{3}$ determined by both 06DS and NOCRB were comparable to the observations.

The additional statistical analysis, root mean square error (RMSE) and normalized bias (NB), for 06DS were $15.6 \mathrm{ppbv}$ and -0.016 , respectively. The daily distributions of OCRB emissions bring about better predictions of $\mathrm{O}_{3}$ compared to 06AA (monthly mean $=75.5 \mathrm{ppbv}, R=0.39$, $\mathrm{RMSE}=18.8 \mathrm{ppbv}$, and $\mathrm{NB}=0.038$ ). Comparison to 00DS (monthly mean $=75.0 \mathrm{ppbv}$ ) suggests the updated anthropogenic emissions contribute to better reproduction in the monthly averaged $\mathrm{O}_{3}$. Influence by smoothing hotspot data is quite small in the $\mathrm{O}_{3}$ prediction, though the negative bias of 06DS is slightly larger than $\mathrm{NB}=-0.008$ of $06 \mathrm{DO}$.

Figure 7 shows time profiles of a major $\mathrm{O}_{3}$ precursor, $\mathrm{NO}_{2}$ concentrations, at Mount Tai by this model (06DS), in situ observation, and Multi Axis Differential Optical Absorption Spectroscopy (MAX-DOAS) (Irie et al., 2008). This model captured reasonably daytime $\mathrm{NO}_{2}$ variation within $0.1-2.0 \mathrm{ppbv}$, though this model could not capture considerably high $\mathrm{NO}_{2}$, more than about 3 ppbv during the highpollution episodes (cf. Irie et al., 2008). For night time $\mathrm{NO}_{2}$, observed hourly concentrations reached 4.5-6.9 ppbv, but this model could not reproduce the high $\mathrm{NO}_{2}$. These underestimations might be caused by problems on temporal resolutions of $\mathrm{NO}_{2}$ emissions from both biomass burning and anthropogenic sectors and an undervaluation of influence by OCRB emissions.

\subsubsection{CO at the summit of Mount Tai}

The reproducibility of simulated $\mathrm{CO}$ in June was much better with 06DS $(R=0.55)$ than with NOCRB $(R=0.11)$ (Fig. 6d).

In particular, in the early half of June, the run 06DS simulated well the high-pollution episodes that could not be reproduced by NOCRB, where the simulated daily CO by 06DS had been increased by 50-480 ppbv compared with the NOCRB case. Meanwhile, the discrepancies between 06DS and observations, the underestimates in model output and the 
one-day delay during the second high-pollution episode (1213 June) discussed Sect. 4.3.1 for ozone were clearly found in day-to-day $\mathrm{CO}$ variations (Fig. 6d). Moreover, simulated monthly CO (306.2 ppbv) including daily OCRB emissions were lower than the observed monthly $\mathrm{CO}$ emissions $(567.7 \mathrm{ppbv})$. This underestimate reached a factor of 1.9 . Even in the latter half of June under less biomass-burning activities, 06DS underestimated daily $\mathrm{CO}$ by a factor of 2 . This suggests the underestimates by the model are due to reasons other than uncertainties in OCRB emissions, especially CO emissions from energy sectors.

Although 06DS tended to underestimate $\mathrm{CO}$, the analysis for 06DS (monthly mean $=309.2 \mathrm{ppbv}, \quad R=0.55$, RMSE $=306.5 \mathrm{ppbv}$, and $\mathrm{NB}=0.41$ ) clearly shows that daily OCRB emissions are helpful for simulating $\mathrm{CO}$ compared to 06AA (monthly mean $=240.9 \mathrm{ppbv}, R=0.53$, $\mathrm{RMSE}=369.4 \mathrm{ppbv}$, and NB $=0.53$ ). The statistical analysis of 06DS and 06DO (monthly mean $=301.0 \mathrm{ppbv}, R=0.53$, $\mathrm{RMSE}=314.9 \mathrm{ppbv}$, and $\mathrm{NB}=0.42$ ) shows a little influence on the simulated $\mathrm{CO}$ by smoothing hotspot data.

\subsubsection{Aerosols at the summit of Mount Tai}

Simulated daily EC concentrations were compared with both the highest values using the MAAP analyzer and the lowest values using the ECOC analyzer in Fig. 6e. Figure $6 \mathrm{f}$ shows the daily concentrations of simulated and observed OC. It should be noted that secondary organic molecules (SOMs) were included in simulated OC. Although a factor of 1.2-1.4 for estimating average organic molecular weight per carbon weight (White and Roberts, 1977) or 1.6 for urban aerosol (Turpin and Lim, 2001) should technically be considered for SOM, we ignored this factor in the present study. BC (or EC) and OC concentrations determined using the ECOC analyzer and the MAAP analyzer, which revealed similar day-to-day variation patterns, were successfully captured by this model simulation using daily OCRB emissions (06DS) with $R=0.64-0.69$ and 0.63 between the model and the observations, respectively (Figs. 6e and f). These are much better than correlations obtained by NOCRB ( $R=0.04-0.15$ for $\mathrm{BC}$ and 0.32 for OC). In particular for the concentrations peaks on 7 June, the daily BC $\left(4 \mu \mathrm{g} \mathrm{m}^{-3}\right)$ and $\mathrm{OC}\left(19 \mu \mathrm{g} \mathrm{m}^{-3}\right)$ concentrations simulated by 06DS were much closer to the observed concentrations $\left(7-10 \mu \mathrm{g} \mathrm{C} \mathrm{m}^{-3}\right.$ for $\mathrm{BC}$ or $\mathrm{EC}$ and $24 \mu \mathrm{g} \mathrm{C} \mathrm{m}{ }^{-3}$ for OC), whereas these peaks could not be simulated by NOCRB. However, BC simulated by 06DS still tended to underestimate by $20-60 \%$ compared with EC determined using the ECOC analyzer (or by $30-$ $80 \%$ when using the MAAP analyzer). For the second highpollution episode (12-13 June), as mentioned in $\mathrm{O}_{3}$ subSect., the same discrepancies as those for $\mathrm{O}_{3}$ and $\mathrm{CO}$ between the model (06DS) and observations were also found in BC and OC (Fig. 6e and f). For the latter half of June, during decreased biomass burning activities, both simulations with (06DS) and without (NOCRB) daily OCRB emis- sions successfully reproduced daily OC concentrations, but tended to underestimate daily $\mathrm{BC}$ concentrations by more than a factor of 2 . In the monthly-averaged concentrations, the model tended to underestimate $\mathrm{BC}$ by more than a factor of 2 (ECOC analyzer) and 3.5 (MAAP analyzer), and OC by a factor of 1.3. This result means that $\mathrm{BC}$ emissions from anthropogenic emissions excluding biomass-burning emissions are likely to be underestimated.

The comparisons of the analysis between 06DS (monthly mean $=1.3 \mu \mathrm{g} \mathrm{C} \mathrm{m}^{-3}, \quad R=0.64-0.69, \quad \mathrm{RMSE}=1.9-$ $3.6 \mu \mathrm{g} \mathrm{m}^{-3}$, and $\mathrm{NB}=0.37-0.57$ for $\mathrm{BC}$ and monthly mean $=6.6 \mu \mathrm{g} \mathrm{C} \mathrm{m}^{-3}, R=0.63$, RMSE $=6.0 \mu \mathrm{g} \mathrm{C} \mathrm{m}^{-3}$, and $\mathrm{NB}=0.15$ for $\mathrm{OC}$ ) and 06AA (monthly mean $=0.8 \mu \mathrm{g} \mathrm{C} \mathrm{m}^{-3}$, $R=0.17-0.21$, RMSE $=2.6-4.2 \mu \mathrm{g} \mathrm{m}^{-3}$, and $\mathrm{NB}=0.52-$

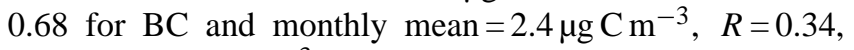
$\mathrm{RMSE}=9.5 \mu \mathrm{g} \mathrm{C} \mathrm{m}{ }^{-3}$, and $\mathrm{NB}=0.64$ for $\mathrm{OC}$ ) demonstrate that the daily OCRB emissions are an essential factor to simulate these aerosol species, even though the run 06DS tends to underestimate those. The results by 06DO showed a little influence on the simulated $\mathrm{BC}$ and $\mathrm{OC}$ by smoothing hotspot data.

In the TRACE-P study, Heald et al. (2003) indicated that a daily resolution of biomass burning emission was not critical for modeling outflow from tropical regions, because they focused on correlation coefficients between the observed and the simulated $\mathrm{CO}$ over outflow regions. By contrast, daily emission values for open biomass burning, especially OCRB, benefit prediction accuracy for air pollutants near the source region. In particular, daily OCRB emissions are absolutely necessary to reproduce the observed $\mathrm{BC}$ and $\mathrm{OC}$ concentrations.

\subsubsection{Other observational sites in China}

The simulated concentrations by 06DS were validated further by comparing the model results with observed concentrations at a few ground sites at East China region, Mount Hua $\left(34^{\circ} \mathrm{N}, 110^{\circ} \mathrm{E}, 2064 \mathrm{~m}\right.$ a.s.l.), Mount Huang $\left(30^{\circ} \mathrm{N}, 118^{\circ} \mathrm{E}, 1836 \mathrm{~m}\right.$ a.s.l.), and Xinglong $\left(40^{\circ} \mathrm{N}, 118^{\circ} \mathrm{E}\right.$, $960 \mathrm{~m}$ a.s.l.) in June 2006 (Table 3). Locations of these sites are shown in Fig. 1. These observation sites are the same spatial representative rural sites as the summit of Mount Tai. The model overestimated observed monthly $\mathrm{O}_{3}$ by $2-23$ ppbv, by contrast with the Mount Tai case. For both of $\mathrm{CO}$ and BC, the model underestimated observations by a factor of 1.1-1.4, and 1.3, respectively. These results suggested that this model has equally reasonable prediction ability over East China region.

\subsubsection{OCRB impacts on pollutants}

Daily atmospheric pollutants $\left(\mathrm{O}_{3}, \mathrm{CO}, \mathrm{EC}\right.$ and $\left.\mathrm{OC}\right)$ and the OCRB impacts on these pollutants distributions close to the ground $(<1 \mathrm{~km})$ are shown in Fig. 8 with surface weather charts and wind patterns for each day within three selected 
Table 3. Comparisons of monthly simulated and observed atmospheric pollutants at three Chinese sites in June 2006.

\begin{tabular}{|c|c|c|c|c|c|c|c|}
\hline site & location & $\begin{array}{l}\mathrm{O}_{3}(\mathrm{ppbv}) \\
\text { observation }\end{array}$ & model & $\begin{array}{l}\mathrm{CO}(\mathrm{ppbv}) \\
\text { observation }\end{array}$ & model & $\begin{array}{l}\mathrm{BC}\left(\mu \mathrm{gm}^{-3}\right) \\
\text { observation }\end{array}$ & model \\
\hline Mount Hua & $34^{\circ} \mathrm{N}, 110^{\circ} \mathrm{E}, 2064 \mathrm{~m}$ a.s.1. & 42.3 & 66.0 & 376.3 & 268.7 & & \\
\hline Mount Huang & $30^{\circ} \mathrm{N}, 118^{\circ} \mathrm{E}, 1836 \mathrm{~m}$ a.s.l. & 65.2 & 70.8 & 228.3 & 206.0 & 0.76 & 0.59 \\
\hline Xinglong $^{\mathrm{a}}$ & $40^{\circ} \mathrm{N}, 118^{\circ} \mathrm{E}, 960 \mathrm{~m}$ a.s.l. & 62.0 & 64.1 & & & & \\
\hline
\end{tabular}

a Bai et al. (2008).

characteristic episodes at the summit of Mount Tai: Episode I-a, the first pollution peak on 7 June; Episode I-b, the second pollution peak on 12 June; Episode II, the relatively cleaner day on 10 June; and Episode III, in non-OCRB conditions on 28 June. The impacts of OCRB on these concentrations were assessed from differences between 06SD and NOCRB.

Both observed pollution peaks on 7 and 12 June, shown as Episode I-a and Episode I-b in Fig. 8, respectively, occurred under similar meteorological conditions controlled by northward and northeastward transport toward a strong low pressure located in northeastern China, particularly in and around east coastal area of CEC. In particular, on 7 June the model captured the pollution episode and was influenced by the higher atmospheric pollutant emissions over southern CEC, which were likely enhanced by OCRB as shown in Fig. 4. The contributions from OCRB on the daily emissions were 44\% $\left(\mathrm{NO}_{2}\right), 60 \%$ (CO), 63\% (PEC) and 69\% (POC), which were much higher than the monthly-averages, $17-45 \%$. This model experiment indicates that OCRB emissions contribute strongly to pollutions concentrations, being responsible for $26 \%$ of $\mathrm{O}_{3}, 62 \%$ of $\mathrm{CO}, 79 \%$ of $\mathrm{EC}$, and $80 \%$ of OC at the summit of Mount Tai. The wide-ranging OCRB impacts over CEC were simulated and found to contribute 12-80\% of the pollutant concentrations over CEC. For 12 June, on the other hand, the daily OCRB emissions over CEC were relatively lower than those on 7 June, with contributions of $26 \%\left(\mathrm{O}_{3}\right), 42 \%(\mathrm{CO}), 45 \%(\mathrm{PEC})$ and $59 \%(\mathrm{POC})$ of the daily totals. As a result, the OCRB impacts on the pollutant concentrations over CEC were relatively low by comparison with Episode I-a on 7 June as shown in Fig. 8, and were 8\% $\left(\mathrm{O}_{3}\right), 33 \%(\mathrm{CO}), 58 \%(\mathrm{EC})$ and $65 \%(\mathrm{OC})$ at the summit of Mount Tai. This suggested again that the underestimate of pollutants during the second high-pollution peak might have been caused by the underestimate of impact of OCRB emissions.

For Episode II on 10 June, enhanced emissions due to OCRB were found over the southern part of CEC (Fig. 4). The contributions from OCRB were still large, forming 26$59 \%$ of the daily emissions. However, the impact of OCRB on pollution concentrations was almost zero at the summit of Mount Tai. As shown in Fig. 8 (Episode II), low-pressure systems stretching from east China to Japan with a stationary front over the western Pacific Ocean brought airflow from north China and Mongolia to CEC through the upper boundary layer. Mount Tai was just behind the strong low pressure system, therefore a highly polluted air mass was advected to the south of Mount Tai, and northern CEC was covered by a cleaner and drier continental air mass originating from the lateral boundary. As a result, the advected polluted air mass containing high pollutant caused by OCRB moved over southern CEC, the East China Sea, and the Korean Peninsula. Meanwhile, the averaged impacts of OCRB emissions contributed $6 \%$ of $\mathrm{O}_{3}$ concentrations, $20 \%$ of $\mathrm{CO}, 43 \%$ of $\mathrm{EC}$ and $53 \%$ of OC over CEC.

The last 10 days of June did not contain any hotspots (Fig. 5), and atmospheric pollutants and their precursors showed lower emissions over CEC than during other episodes, as shown in Figs. 2 and 4. The negligible impact of OCRB on daily emissions as compared with monthlyaveraged emissions in Episode III. These results demonstrate that the impact of OCRB on all pollutant concentrations was almost zero over CEC, including Mount Tai, on 28 June.

\subsection{Uncertainties}

This study is the first model experiment using a new daily OCRB emissions inventory for an intensive observation campaign, MTX2006 in CEC. On the other model setting, therefore, this study employed our conventional model system because the predictive performances were checked well in our previous studies (Yamaji et al., 2006, 2008). On the other hand, uncertainties in this model system attributed from a large number of factors might make influence on simulated concentrations.

An important factor relates to input-elements for the regional CTM run. For anthropogenic CO, previous studies for TRACE-P have suggested that ACESS (Streets et al., 2003), especially for Chinese CO emissions, was also underestimated by around 50\% (Carmichael et al., 2003; Palmer et al., 2003; Wang et al., 2004; Tan et al., 2004). Carmichael et al. (2003) indicated that the domestic sector would have to be increased by $3-5$ times to reconcile the model results for $\mathrm{CO}$ with the observations. On the basis of these results, Streets et al. (2006) revised China's CO emissions to $157 \mathrm{Tg}$ in 2001, which was $36 \%$ higher than the previous estimate for the year 2000 of $116 \mathrm{Tg}$ (Streets et al., 2003), and indicated that estimates of $\mathrm{CO}$ from China should be in the 

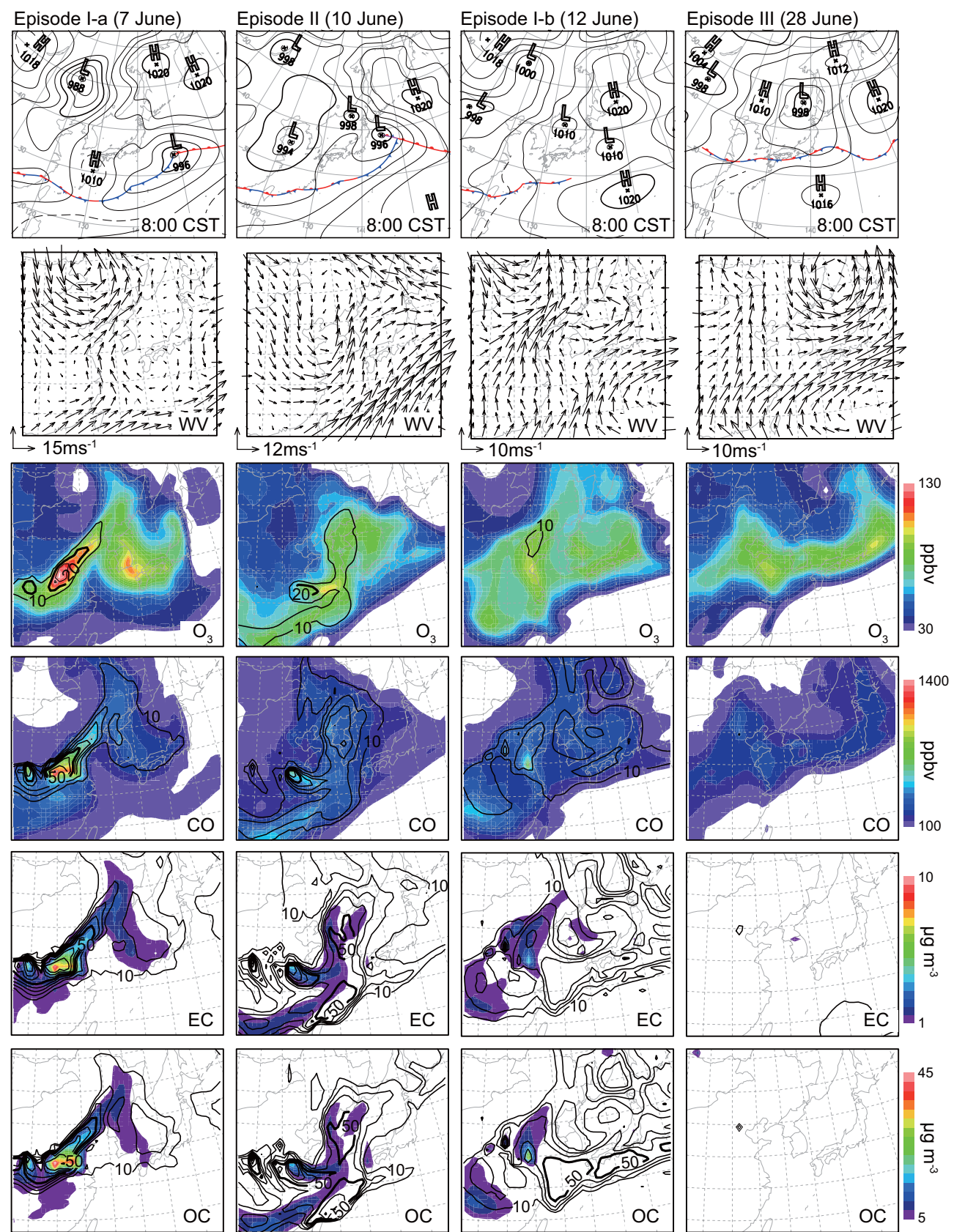

Fig. 8. Spatial distributions of surface meteorological fields and simulated atmospheric concentrations for Episode I-a on 7 June, Episode I-b on 12 June, Episode II on 10 June, and Episode III on 28 June 2006 over East Asia. Top four panels: The surface weather chart at 08:00 CST/00:00 UTC for each day is also shown on the top line from Japan Meteorological Agency (http://www.data.jma.go.jp/fcd/yoho/ hibiten/index.html). The second four panels are: Simulated wind fields below approximately $1000 \mathrm{~m}$ altitude. Bottom panels: $\mathrm{O}_{3}, \mathrm{CO}, \mathrm{EC}$ and $\mathrm{OC}$ concentrations (colors), approximately $<1000 \mathrm{~m}$ altitude. Contours are impacts of open crop residual burning in China (\%): thick solid lines are drawn each $20 \%$ for $\mathrm{O}_{3}$ and $50 \%$ for $\mathrm{CO}, \mathrm{BC}$, and $\mathrm{OC}$; thin solid lines are drawn each $10 \%$ for $\mathrm{O}_{3}, \mathrm{CO}, \mathrm{BC}$, and $\mathrm{OC}$. The impacts are calculated from the differences between 06DS and the other simulation without emissions from open crop residual burning in China.

order of $140-200 \mathrm{Tg} \mathrm{yr}^{-1}$. Our anthropogenic emission inventory with $141 \mathrm{Tg} \mathrm{yr}^{-1} \mathrm{CO}$ from China in 2001 (Ohara et al., 2007) might still be too low. In emissions from biomass burning, it is noted that there is a $90 \%$ uncertainty in annual
CO. A half of this variance stems from uncertainties in $\mathrm{CO}$ emission factors, especially the emission factor for OCRB (Yan et al., 2006). Emissions of BC and OC in China would include larger uncertainties, of $484 \%$ for BC and $495 \%$ for 
OC as compared with CO (156\%), in an Asian scale emission inventory (ACESS) assimilated using the same bottomup method (Streets et al., 2003). This model system includes highly uncertainty in natural emissions as mentioned in the section above. For long-lived pollutants such as $\mathrm{CO}$, inflow into the regional model domain is also a major factor. Boundary $\mathrm{CO}$ concentrations from CHASER likely influence underestimates of $\mathrm{CO}$, because the simulated $\mathrm{CO}$ by the AGCM tended to be lower than observations by a few to $50 \mathrm{ppbv}$ in June at most sites in the northern hemisphere (Sudo et al., 2002b).

In the aerosol module, AERO3 is a simple aerosol module by comparison with the latter modules in CMAQ, e.g. AERO5 and model of aerosol dynamics, reaction, ionization, and dissolution (MADRID). Including heterogeneous reactions altered hourly $\mathrm{O}_{3}$ values by up to $17 \%$ and daily $\mathrm{PM}_{2.5}$ by up to $3 \%$. However, organic aerosol was under-predicted at most sites in the Los Angeles basin even by the latter module (Zhang et al., 2004). The newer aerosol modules will adapt to East Asian air quality study in future.

Additionally, it should be noted that this model could not reproduce the diurnal variation with daytime peaks associated with both the build-up of the planetary boundary layer (Kanaya et al., 2008) and the upslope motion of polluted air masses. The observed $\mathrm{O}_{3}$ concentrations showed a weak valley between 14:00 and 17:00, with an amplitude of only 3 ppbv for concentration, not captured in the simulation. This matter might affect on underestimation of $\mathrm{NO}_{2}$ as mentioned above. The other reason for the underestimation of $\mathrm{NO}_{2}$ is possibly attributed to too much decreased $\mathrm{NO}_{2}$ in this model near surface at daytime. These uncertainties will be subject to our future studies.

\section{Summary}

The impact of open crop residual burning (OCRB) on $\mathrm{O}_{3}$, $\mathrm{CO}, \mathrm{BC}$ (or EC), and $\mathrm{OC}$ concentrations at the summit of Mount Tai located at the center of Central Eastern China (CEC), was evaluated using a regional chemical transport model (CMAQ) and daily biomass burning emissions data.

Firstly, to simulate the pollutant concentrations in the MTX2006, we developed a new daily biomass burning emission inventory, including in particular the daily OCRB emissions based on a bottom-up methodology, and using land cover and hotspot information from satellites. The daily OCRB emissions over CEC in June were approximately $40 \%$ of the annual total. Approximately $14 \%$ of monthly total (about $6 \%$ of annual total) of the OCRB emissions were concentrated in 7 June.

The MTX2006 period was roughly divided into two parts: 1) polluted days with heavy OCRB in the first half of June; and 2) cleaner days with negligible field burning in the latter half of June. Additionally, the first half of June was characterized by two high-pollution episodes during 5-7 and 12-13
June, separated by a relatively cleaner intermediate episode during 8-10 June. These episodes were strongly associated with OCRB emissions and wind direction over CEC.

The model could reasonably capture observed-daily wind patterns at the summit of Mount Tai in June 2006. The model experiment $06 \mathrm{DS}$ coupled with a new daily biomass burning emission inventory based on smoothed hotspot data and estimated an anthropogenic emission inventory, REAS for the year 2006, successfully reproduced $\mathrm{O}_{3}, \mathrm{CO}, \mathrm{BC}$ and $\mathrm{OC}$ concentrations and their day-to-day variations with correlation coefficients $(R)$ of $0.610 .55,0.64-0.69$, and 0.63 , respectively, between the model and the observation. For early June, especially on 7 June, the model using daily OCRB emissions successfully captured the high pollution concentrations. For the second-pollution episode on 12-13 June, however, this model showed a one-day delay in the pollution peak. The study suggested that this one-day delay was affected by both underestimation of OCRB emissions and uncertainties in modeled wind direction.

The comparison between 06DS (using smoothed hotspot data) and 06DO (observed hotspot data) showed the smoothing of hotspot data has little merit for model performance. For example, R calculated by 06DS (0.55-0.69) was better than $\mathrm{R}$ calculated by 06DO (0.35-0.66). 06DS results were much better than those obtained by both 06AA (using annual biomass burning emissions) and 00DS (using REAS in 2000).

The high-pollution episode at the summit of Mount Tai on 7 June was mainly a result of high OCRB and strong northward and northeastward transport over CEC. On 7 June, OCRB emissions formed large contributions to total pollutant concentrations, constituting $26 \%$ of $\mathrm{O}_{3}, 62 \%$ of $\mathrm{CO}$, $79 \%$ of EC and $80 \%$ of OC. The wide-ranging OCRB impacts on CEC were simulated. By contrast, the last 10 days of June did not contain any hotspots, therefore the impact of OCRB on all pollutant concentrations was almost zero over CEC on 28 June.

The model underestimated both daily-averaged $\mathrm{CO}$ and $\mathrm{BC}$ by a factor of 2, using emission data from almost anthropogenic fuel sources, even in the latter half of the observation period where field burning could be neglected. This suggested that anthropogenic emissions excepting biomass burning were still underestimated.

\section{Supplementary material related to this article is available online at: http://www.atmos-chem-phys.net/10/7353/2010/ acp-10-7353-2010-supplement.pdf.}


Acknowledgements. MODIS data were obtained from the Institute of Industrial Science website, University of Tokyo. This work was supported by the Grants-in-Aid of Scientific Research (No. 19710024) from the Ministry of Education, the Global Environment Research Fund of the Ministry of the Environment, Japan (No. B-051, C-081, S-7), and the Joint Research Fund of the Research Institute for Applied Mechanics, Kyusyu University (No. 21AO-14).

Edited by: S. C. Liu

\section{References}

Acker, J. G. and Leptoukh, G.: Online analysis enhances use of NASA earth science data, Eos, Trans. AGU, 88, 14-17, doi:10.1029/2007EO020003, 2007.

Akimoto, H., Ohara, T., Kurokawa, J., and Horii, N.: Verification of energy consumption in China during 1996-2003 by using satellite observational data, Atmos. Environ., 40, 7663-7667, doi:10.1016/j.atmosenv.2006.07.052, 2006.

Allen, D., Pickering, K., and Fox-Rabinovitz, M.: Evaluation of pollutant outflow and CO sources during TRACE-P using model-calculated, aircraft-based, and Measurements of Pollution in the Troposphere (MOPITT)-derived CO concentrations, J. Geophys. Res., 109, D15S03, doi:10.1029/2003JD004250, 2004.

Andreae, M. O. and Merlet, P.: Emission of trace gases and aerosols from biomass burning, Global Biogeochem. Cy., 15, 955-966, 2001.

Arellano, A. F., Kasibhatla, P. S., Giglio, L., van der Werf, G. R., and Randerson, J. T.: Top-down estimates of global CO sources using MOPITT measurements, Geophys. Res. Lett., 31, L01104, doi:10.1029/2003GL018609, 2004.

Bai, J., Wang, P., and Wang, G.: Basic Characteristics of main trace gases in the surrounding area of Beijing, in Chinese, Sci. Technol. Eng., 8, 2323-2330, 2008.

Binkowski, F. S. and Shankar, U.: The Regional Particulate Matter Model, 1. Model description and preliminary results, J. Geophys. Res., 100, 26191-26209, 1995.

Byun, D. W. and Ching, J. K. S. (Eds.): Science algorithms of the EPA Models-3 community multiscale air quality (CMAQ) modeling system, EPA/600/R-99/030, USEPA NERL, Research Triangle Park, USA, 1999.

Cao, G., Zhang, X., Wang, D., and Zheng, F.: Inventory of atmospheric pollutants discharged from biomass burning in China continent, in Chinese, China Environ. Sci., 25, 389-393, 2005.

Carmichael, G. R., Tang, Y., Kurata, G., Uno, I., Streets, D. G., Thongboonchoo, N., Woo, J.-H., Guttikunda, S., White, A., Wang, T., Blake, D. R., Atlas, E., Fried, A., Potter, B., Avery, M. A., Sachse, G. W., Sandholm, S. T., Kondo, Y., Talbot, R. W., Bandy, A, Thorton, D., and Clarke, A. D.: Evaluating regional emission estimates using the TRACE-P observations, J. Geophys. Res., 108, 8810, doi:10.1029/2002JD003116, 2003.

Carter, W. P. L.: Documentation of the SAPRC-99 chemical mechanism for VOC reactivity assessment. Final report to California Air Resource Board, UC Riverside, CA, USA, Contract No. 92329 and 95-308, 2000.

Cotton, W. R., Pielke, R. A., and Walko, R. L.: RAMS 2001: Current status and future directions, Meteorol. Atmos. Phys. 82, 5-
29, 2003.

Editorial Board of China Agricultural Statistical Yearbook: China Agricultural Statistical Yearbook 2006, in Chinese, China Agricultural Press, Beijing, China, 2007.

Gao, J., Wang, T., Ding, A., and Liu, C.: Observational study of ozone and carbon monoxide at the summit of mount Tai (1534ma.s.1.) in central-eastern China, Atmos. Environ., 39, 4779-4791, doi:10.1016/j.atmosenv.2005.04.030, 2005.

Guenther, A., Hewitt, C. N., Erickson, D., Fall, R., Geron, C., Graedel, T., Harley, P., Klinger, L., Lerdau, M., Mckay, W. A., Pierce, T., Scholes, B., Steinbrecher, R., Tallamraju, R., Taylor, J., and Zimmerman, P.: A global model of natural volatile organic compound emissions, J. Geophys. Res., 100, 8873-8892, doi:10.1029/94JD02950, 1995.

He, Y. J., Uno, I., Wang, Z. F., Pochanart, P., Li, J., and Akimoto, H.: Significant impact of the East Asia monsoon on ozone seasonal behavior in the boundary layer of Eastern China and the west Pacific region, Atmos. Chem. Phys., 8, 7543-7555, doi:10.5194/acp-8-7543-2008, 2008.

Irie, H., Sudo, K., Akimoto, H., Richter, A., Burrows, J. P., Wagner, T., Wenig, M., Beirle, S., Kondo, Y., Sinyakov, V. P., and Goutail, F.: Evaluation of long-term tropospheric $\mathrm{NO}_{2}$ data obtained by GOME over East Asia in 1996-2002, Geophys. Res. Lett., 32, L11810, doi:10.1029/2005GL022770, 2005.

Irie, H., Kanaya, Y., Akimoto, H., Tanimoto, H., Wang, Z., Gleason, J. F., and Bucsela, E. J.: Validation of OMI tropospheric NO2 column data using MAX-DOAS measurements deep inside the North China Plain in June 2006: Mount Tai Experiment 2006, Atmos. Chem. Phys., 8, 6577-6586, doi:10.5194/acp-86577-2008, 2008.

Irie, H., Kanaya, Y., Takashima, H., Gleason, F. J., and Wang, Z.: Characterization of OMI Tropospheric $\mathrm{NO}_{2}$ Measurements in East Asia Based on a Robust Validation Comparison, SOLA, 5, 117-120, 2009.

Kanaya, Y., Komazaki, Y., Pochanart, P., Liu, Y., Akimoto, H., Gao, J., Wang, T., and Wang, Z.: Mass concentrations of black carbon measured by four instruments in the middle of Central East China in June 2006, Atmos. Chem. Phys., 8, 7637-7649, doi:10.5194/acp-8-7637-2008, 2008.

Kanaya, Y., Pochanart, P., Liu, Y., Li, J., Tanimoto, H., Kato, S., Suthawaree, J., Inomata, S., Taketani, F., Okuzawa, K., Kawamura, K., Akimoto, H., and Wang, Z. F.: Rates and regimes of photochemical ozone production over Central East China in June 2006: a box model analysis using comprehensive measurements of ozone precursors, Atmos. Chem. Phys., 9, 7711-7723, doi:10.5194/acp-9-7711-2009, 2009.

Kasibhatla, P., Arellano, A., Logan, J. A., Palmer, P. I., and Novelli, P.: Top-down estimate of a large source of atmospheric carbon monoxide associated with fuel combustion in Asia, Geophys. Res. Lett., 29, 1900, doi:10.1029/2002GL015581, 2002.

Kiley, C. M., Fuelberg, H. E., Palmer, P. I., Allen, D. J., Carmichael, G. R., Jacob, D. J., Mari, C., Pierce, R. B., Pickering, K. E., Tang, Y., Wild, O., Fairlie, T. D., Logan, J. A., Sachse, G. W., Shaack, T. K., and Streets, D. G.: An intercomparison and evaluation of aircraft-derived and simulated $\mathrm{CO}$ from seven chemical transport models during the TRACE-P experiment, J. Geophys. Res., 108, 8819, J. Geophys. Res., doi:10.1029/2002JD003089, 2003.

Li, J., Wang, Z., Akimoto, H., Gao, C., Pochanart, P., and Wang, X.: Modeling study of ozone seasonal cycle in lower 
troposphere over East Asia, J. Geophys. Res., 112, D22S25, doi:10.1029/2006JD008209, 2007.

Li, J., Wang, Z., Akimoto, H., Yamaji, K., Takigawa, M., Pochanart, P., Liu, Y., Tanimoto, H., and Kanaya, Y.: Nearground ozone source attributions and outflow in central eastern China during MTX2006, Atmos. Chem. Phys., 8, 7335-7351, doi:10.5194/acp-8-7335-2008, 2008.

Li, J., Pochanart, P., Wang, Z., Liu, Y., Yamaji, K., Takigawa, T., Kanaya, Y., and Akimoto, H.: Impact of chemical production and transport on summertime diurnal ozone behavior at a mountainous site in North China Plain, SOLA, 4, 121-124, 2008 b.

MOA/DOE Project Expert Team: Assessment of biomass resource availability in China, China Environmental Science Press, Beijing, China, 1998.

Nenes, A., Pilinis, C., and Pandis, S. N.: A new thermodynamic equilibrium model for multiphase multicomponent inorganic aerosols, Aquat. Geoch., 4, 123-152, 1998.

Ohara, T., Akimoto, H., Kurokawa, J., Horii, N., Yamaji, K., Yan, X., and Hayasaka, T.: An Asian emission inventory of anthropogenic emission sources for the period 1980-2020, Atmos. Chem. Phys., 7, 4419-4444, doi:10.5194/acp-7-4419-2007, 2007.

Olivier, J. G. J., Bloos, J. P. J., Berdowski, J. J. M., Visschedijk, A. J. H., and Bouwman A. F.: A 1990 global emission inventory of anthropogenic sources of carbon monoxide on $1 \times 1$ degree developed in the framework of EDGAR/GEIA, Chemosphere: Global Change Sci., 1, 1-17, 1999.

Palmer, P. I., Jacob, D. J., Jones, D. B. A., Heald, C. L., Yantosca, R. M., Logan, J. A., Sachse, G. W., and Streets, D. G.: Inverting for emissions of carbon monoxide from Asia using aircraft observations over the western Pacific, J. Geophys. Res., 108, 8828, doi:10.1029/2003JD003397, 2003.

Pétron, G., Granier, C., Khattatov, B., Lamarque, J., Yudin, V., Müller, J., and Gille, J.: Inverse modeling of carbon monoxide surface emissions using Climate Monitoring and Diagnostics Laboratory network observations, J. Geophys. Res., 107, 4761, doi:10.1029/2001JD001305, 2002.

Pielke, R. A., Cotton, W. R., Walko, R. L., Tremback, C. J., Lyons, W. A., Grasso, L. D., Nicholls, M. E., Moran, M. D., Wesley, D. A., Lee, T. J., and Copeland, J. H.: A comprehensive meteorological modeling system-RAMS, Meteorol. Atmos. Phys., 49, 69-91, 1992.

Richter, A., Burrows, J. P., Nüß, H., Granier, C., and Niemeier, U.: Increase in tropospheric nitrogen dioxide over China observed from space, Nature, 437, 129-132, doi:10.1038/nature04092, 2005.

Schell, B., Ackermann, I. J., Hass, H., Binkowski, F. S., and Ebel, A.: Modeling the formation of secondary organic aerosol within a comprehensive air quality model system. J. Geophys. Res., 106, 28275-28293, 2001.

Song, J. B.: Survey and analysis of crop residue resources and quality in Zhejing Province, in Chinese, Soil Fertil., 2, 23-24, 1995.

Stavrakou, T., Müller, J.-F., De Smedt, I., Van Roozendael, M. van der Werf, G. R., Giglio, L., and Guenther, A.: Evaluating the performance of pyrogenic and biogenic emission inventories against one decade of space-based formaldehyde columns, Atmos. Chem. Phys., 9, 1037-1060, doi:10.5194/acp-9-1037-2009, 2009.

Streets, D. G. and Waldhoff, S. T.: Present and future emissions of air pollutants in China: $\mathrm{SO}_{2}, \mathrm{NO}_{\mathrm{x}}$ and $\mathrm{CO}$, Atmos. Environ., 34, 363-374, 2000a.

Streets, D. G., Tsai, N. Y., Akimoto, H., and Oka, K.: Sulfur dioxide emissions in Asia in the period 1985-1997, Atmos. Environ., 34 4413-4424, doi:10.1016/S1352-2310(00)00187-4, 2000b.

Streets, D. G., Bond, T. C., Carmichael, G. R., Fernandes, S. D., Fu, Q., He, D., Klimont, Z., Nelson, S. M., Tsai, N. Y., Wang, M.Q., Woo, J.-H., and Yarber, K. F.: An inventory of gaseous and primary aerosol emissions in Asia in the year 2000, J. Geophys Res., 108, 8809, doi:10.1029/2002JD003093, 2003.

Streets, D. G., Zhang, Q., Wang, L., He, K., Hao, J., Wu, Y.,Tang, Y., and Carmichael, G. R.: Revisiting China's CO emissions after the transport and chemical evolution over the $\mathrm{Pa}-$ cific (TRACE-P) mission: synthesis of inventories, atmospheric modeling, and observations, J. Geophys. Res., 111, D14306, doi:10.1029/2006JD007118, 2006.

Sudo, K., Takahashi, M., Kurokawa, J., and Akimoto, H.: CHASER: A global chemical model of the troposphere 1. Model description, J. Geophys. Res., 107, 4339, doi:10.1029/2001JD001113, 2002a.

Sudo, K., Takahashi, M., and Akimoto, H.: CHASER: A global chemical model of the troposphere 2. Model results and evaluation, J. Geophys. Res., 107, doi:10.1029/2001/JD001114, 2002b.

Sudo, K. and Akimoto, H.: Global source attribution of tropospheric ozone: Long-range transport from various source regions, J. Geophys. Res., 112, D12302, doi:10.1029/2006JD007992, 2007.

Tan, Q., Chameides, W. L., Streets, D., Wang, T., Xu, J., Bergin, M., and Woo, J.: An evaluation of TRACE-P emission inventories from China using a regional model and chemical measurements, J. Geophys. Res., 109, D22305, doi:10.1029/2004JD005071, 2004.

Turpin B. J. and Lim H.-J.: Species contributions to $\mathrm{PM}_{2.5}$ mass concentrations: revisiting common assumptions for estimating organic mass, Aerosol Sci. Technol., 35, 602-610, 2001.

Uno, I., He, Y., Ohara, T., Yamaji, K., Kurokawa, J.-I., Katayama, M., Wang, Z., Noguchi, K., Hayashida, S., Richter, A., and Burrows, J. P.: Systematic analysis of interannual and seasonal variations of model-simulated tropospheric NO2 in Asia and comparison with GOME-satellite data, Atmos. Chem. Phys., 7, 16711681, doi:10.5194/acp-7-1671-2007, 2007.

White, W. H. and Roberts, P. T.: On the nature and origins of visibility-reducing aerosols in the Los Angeles Air Basin, Atmos. Environ., 11, 803-812, doi:10.1016/0004-6981(77)900427, 1977.

Yamaji, K., Ohara, T., and Akimoto, H.: A country-specific, high resolution emission inventory for methane from livestock in Asia in 2000, Atmos. Environ., 37, 4393-4406, doi:10.1016/S13522310(03)00586-7, 2003.

Yamaji, K., Ohara, T., and Akimoto, H.: Regional-specific emission inventory for $\mathrm{NH}_{3}, \mathrm{~N}_{2} \mathrm{O}$, and $\mathrm{CH}_{4}$ via animal farming in South, Southeast, and East Asia, Atmos. Environ., 38, 71117121, doi:10.1016/j.atmosenv.2004.06.045, 2004.

Yamaji, K., Ohara, T., Uno, I., Tanimoto, H., Kurokawa, J., and Akimoto, H.: Analysis of the seasonal variation of ozone in the boundary layer in East Asia using the Community Multiscale Air Quality model: What controls surface ozone levels over Japan?, Atmos. Environ., 40, 1856-1868, doi:10.1016/j.atmosenv.2005.10.067, 2006. 
Yamaji, K., Ohara, T., Uno, I., Kurokawa, J., Pochanart, P., and Akimoto, H.: Future prediction of surface ozone over east Asia using models -3 community multiscale air quality modeling system and regional emission inventory in Asia, J. Geophys. Res., 113, D08306, doi:10.1029/2007JD008663, 2008.

Yan, X., Akimoto, H., and Ohara, T.: Estimation of nitrous oxide, nitric oxide, and ammonia emissions from croplands in East, Southeast, and South Asia, Global Change Biol., 9, 1080-1096, 2003.

Yan, X., Ohara, T., and Akimoto, H.: Bottom-up estimate of biomass burning in mainland China, Atmos. Environ., 40, 52625273, doi:10.1016/j.atmosenv.2006.04.040, 2006.

Yang, S. J.: Emphasizing the use of crop residue as energy source, Rural Energy, in Chinese, 58, 18-19, 1994.
Zhang, M. G., Uno, I., Sugata, S., Wang, Z. F., Byun, D., and Akimoto, H.: Numerical study of boundary layer ozone transport and photochemical production in east Asia in the wintertime, Geophys. Res. Lett., 29, doi:10.1029/2001GL014368, 2002.

Zhang, Q., Streets, D. G., Carmichael, G. R., He, K. B., Huo, H., Kannari, A., Klimont, Z., Park, I. S., Reddy, S., Fu, J. S., Chen, D., Duan, L., Lei, Y., Wang, L. T., and Yao, Z. L.: Asian emissions in 2006 for the NASA INTEX-B mission, Atmos. Chem. Phys., 9, 5131-5153, doi:10.5194/acp-9-5131-2009, 2009.

Zhang, Y., Pun, B., Vijayaraghavan, K., Wu, S.-Y., Seigneur, C., Pandis, S., Jacobson, M., Nenes, A., and Seinfeld, J. H.: Development and application of the model of aerosol dynamics, reaction, ionization and dissolution (MADRID), J. Geophys. Res., 109, D01202, doi:10.1029/2003JD003501,2004. 